\title{
(-)-Hydroxycitric Acid Reduced Lipid Droplets Accumulation Via Decreasing Acetyl-Coa Supply and Accelerating Energy Metabolism in Cultured Primary Chicken Hepatocytes
}

\author{
Longlong Li Mengling Peng Chongyang Ge Lei Yu Haitian Ma
}

Key Laboratory of Animal Physiology and Biochemistry, College of Veterinary Medicine, Nanjing Agricultural University, Nanjing, China

\section{Key Words}

(-)-Hydroxycitric acid • Acetyl-CoA • ATP-citrate - Energy metabolism - Primary chicken hepatocytes

\begin{abstract}
Background/Aims: (-)-Hydroxycitric acid (HCA) had been shown to suppress fat accumulation in animals and humans, while the underlying biochemical mechanism is not fully understood, especially little information is available on whether (-)-HCA regulates energy metabolism and consequently affects fat deposition. Methods: Hepatocytes were cultured for $24 \mathrm{~h}$ and then exposed to (-)-HCA $(0,1,10,50 \mu \mathrm{M})$, enzyme protein content was determined by ELISA; lipid metabolism gene mRNA levels were detected by RT-PCR. Results: (-)-HCA significantly decreased the number and total area of lipid droplets. ATP-citrate lyase, fatty acid synthase and sterol regulatory element binding protein-1c mRNA level were significantly decreased after (-)-HCA treatment, whereas peroxisome proliferator-activated receptor $\alpha$ mRNA level was significantly increased. (-)-HCA significantly decreased ATP-citrate lyase activity and acetyl-CoA content in cytosol, but significantly increased glucose consumption and mitochondrial oxygen consumption rate. (-)-HCA promoted the activity/content of glucokinase, phosphofructokinase-1, pyruvate kinase, pyruvate dehydrogenase, citrate synthase, aconitase, succinate dehydrogenase, malate dehydrogenase, NADH dehydrogenase and ATP synthase remarkably. Conclusions: (-)-HCA decreased lipid droplets accumulation by reducing acetylCoA supply, which mainly achieved via inhibition of ATP-citrate lyase, and accelerating energy metabolism in chicken hepatocytes. These results proposed a biochemical mechanism of fat reduction by (-)-HCA in broiler chickens in term of energy metabolism.
\end{abstract}




\section{Cellular Physiology Cell Physiol Biochem 2017;43:812-831

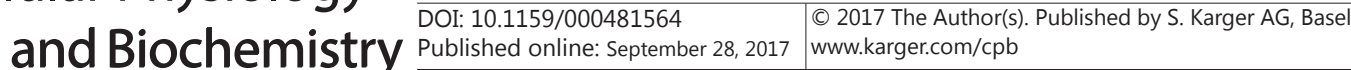 \\ Li et al.: Impact of (-)-HCA On Lipid Metabolism and Energy Metabolism}

\section{Introduction}

Obesity is one of the biggest threats to human health, and the growing problem of obesity is associated with multiple morbidities [1], including increased risk of diabetes, cardiovascular disease, hypertension, heart disease, and fatty liver disease [2-5]. These diseases affect millions of individuals who must carefully control their blood glucose levels to prevent diabetes-related complications $[6,7]$. The biology of obesity is very complex, and mechanisms linking obesity to various diseases are poorly understood [2]. Much attention has been focused on using various bioactive compounds to control obesity [8], while most of these study investigate the effects of lipid metabolism-related factors on fat accumulation control in animals and humans [7, 9-12]. Recently, there has been increasing concern about obesity associated with glucose metabolism [13-15].

$(-)$-Hydroxycitric acid (HCA) is the major active ingredient present in the fruit rind of Garcinia cambogia [16-18]. Previous studies had reported that (-)-HCA increases weight loss $[19,20]$, promotes energy expenditure [21-23], increases the rate of glycogen synthesis [24] and suppresses de novo fatty acid synthesis [25-27]. Recently, our laboratory found that (-)HCA treatment promoted protein synthesis and enhanced energy expenditure in male rats [28]. In addition, we also found that (-)-HCA inhibited fatty acid synthesis by reducing the acetyl-CoA supply via promotion of the citric acid cycle and inhibition of NADP-dependent malic enzyme expression in broiler chickens [29]. Furthermore, previous studies have shown that (-)-HCA is a potent competitive inhibitor of ATP-citrate lyase [25, 26, 30-32], a cytosolic (extra-mitochondrial) enzyme that catalyzes the cleavage of citrate to oxaloacetate and acetyl-CoA, which eventually limits the availability of acetyl-CoA units required for fatty acid synthesis and lipogenesis in animals and humans [21,33].

$(-)$-HCA is structurally similar to citrate. Citrate is an allosteric regulator for a number of enzymes that are involved in carbohydrate and fat metabolism, such as phosphofructokinase (the enzyme regulating glycolysis) [33] and acetyl-CoA carboxylase (the enzyme regulating fatty acid synthesis) [34]. It had been reported that (-)-HCA has a much greater affinity to the citrate lyase than that to citrate [22,35]. Thus, (-)-HCA supplementation is expected to alter metabolic pathways. Although some studies have shown (-)-HCA possesses antiobesity activity [36, 37] and anti-diabetic activity [38, 39], little information is available on whether (-)-HCA affects fat accumulation in broiler chickens through regulation on the energy metabolism.

Unlike mammalian species, the liver is the most important organ of de novo fatty acid synthesis $[35,40]$ and energy metabolism [41] in poultry. Therefore, the present study was conducted to investigate the effects of the (-)-HCA on lipid metabolism and energy metabolism in cultured primary chicken hepatocytes, which will provide useful information for further understanding of the biochemical mechanisms associated with the fat accumulation regulation by (-)-HCA in broiler chicken.

\section{Materials and Methods}

\section{Reagents}

(-)-hydroxycitric acid (HCA) was obtained from USP reference standard (USA). All chicken ELISA kits were purchased from Shanghai Hengyuan Biological Technology Co. (China). Medium 199 was purchased from Hyclone Laboratories (Grand Island, NY, USA); MTT, transferrin, trypsin, penicillin and streptomycin were purchased from Sigma (USA). Glutamine and HEPES were obtained from Amresco (Solon, OH, USA); TRIZOL reagent kit was purchased from Invitrogen (CA, USA). M-MLV reverse transcriptase, RNase inhibitor and dNTP mixture were obtained from Promega (Madison, USA).and SYBR Green PCR Master Mix came from Roche (Basel, Switzerland). Triglyceride assay kit and Oil red staining assay kit were bought from Jian Chen Biotechnology Institution (Nanjing, China). 


\section{Cellular Physiology Cell Physiol Biochem 2017;43:812-831 \begin{tabular}{l|l} 
and Biochemistry Published ontine' September 28, 2017 & $\begin{array}{l}\text { (c) } 2017 \text { The Author(s). Published by S. Karger AG, Basel } \\
\text { www.karger.com/cpb }\end{array}$
\end{tabular}}

Li et al.: Impact of (-)-HCA On Lipid Metabolism and Energy Metabolism

\section{Isolation of hepatocytes}

Fertilized avian chicken eggs were purchased from a commercial hatching factory and incubated at 37 ${ }^{\circ} \mathrm{C}$ under a relative humidity of $60 \%$. The culture of primary embryonic hepatocytes was conducted according to the method described by Kennedy et al [42]. The embryos were sacrificed by decapitation on incubation day 9, and the livers were removed under sterile conditions and washed with cold PBS (phosphate-buffered saline). After washed with M199 medium, the livers were aseptically minced into small fragments (about 1 $\mathrm{mm}^{3}$ ) by eye scissors and suspended in fresh medium for 1-2 min. Then the supernatant was aspirated. Most erythrocytes can be removed after the above procedure has been repeated three to four times. The liver tissues were incubated in PBS ( $\mathrm{Ca}^{2+}$ and $\mathrm{Mg}^{2+}$ free) trypsin solution $(0.25 \mathrm{mg} / \mathrm{mL})$ in a vibrating water-bath ( $90 \mathrm{cycles} / \mathrm{min}$ at $37^{\circ} \mathrm{C}$ ) for $10-15 \mathrm{~min}$. Meanwhile, the solution was mixed frequently by pipette in order to facilitate cell dissociation, until each aggregate consisted of 3-5 cells. The hepatocytes were collected by centrifugation (1000 rpm, $5 \mathrm{~min}$ ) and filtrated through a $150-\mu \mathrm{m}$ mesh. The material was washed three times with fresh M199 medium, and the cell number was determined using a hemacytometer. Cell viability was determined by the Trypan blue exclusion test; the survival rate was greater than $90 \%$ [43].

\section{Primary culture of chicken hepatocytes}

Primary chicken hepatocytes were seed in monolayers in 6-well or 96-well plastic culture plates (Corning, USA) with a density of $2 \times 10^{6}$ cells per well in $2 \mathrm{~mL}$ or $1 \times 10^{5}$ cells per well in $100 \mu \mathrm{L}$ serum-free M199 medium. Supplements were added: including $5 \mathrm{mg} / \mathrm{mL}$ transferrin, $2 \mathrm{mM}$ glutamine and $1.75 \mathrm{mM}$ HEPES. The culture medium also contained $100 \mathrm{IU} / \mathrm{mL}$ penicillin and $100 \mu \mathrm{g} / \mathrm{mL}$ streptomycin. Hepatocytes were incubated at $37{ }^{\circ} \mathrm{C}$ in an atmosphere of $95 \%$ air and $5 \% \mathrm{CO}_{2}$. Following $24 \mathrm{~h}$ acclimatization to the culture environment, cells were cultured for $24 \mathrm{~h}$ in phenol-red and FBS-free M199 medium.

\section{Cell viability assay}

Cells were seeded on 96 -well plates at $1 \times 10^{5}$ cells per well, and treated with $0,1,10$ or $50 \mu \mathrm{M}(-)-\mathrm{HCA}$ for $1,3,6,12$ or $24 \mathrm{~h}$ before addition of MTT solution. Twenty microliter of $5 \mathrm{mg} / \mathrm{mL}$ MTT were added to each well. Four hours later, the culture medium was removed and the formed blue formazan crystals were dissolved in $150 \mu \mathrm{L}$ DMSO. The optical density of the formazan generated from MTT was measured at 490 nm using a model 550 Microplate reader (Bio-Rad, California, USA).

\section{Assessment of cell death rate by Lactate dehydrogenase (LDH) test}

Cells were grown in 96-well plates $\left(1 \times 10^{5}\right.$ cells per well)and treated with $0,1,10$ or $50 \mu \mathrm{M}$ at $1 \times 10^{5}$ cells per well with $100 \mu \mathrm{L}$ cultures medium for $1,3,6,12$ or $24 \mathrm{~h}$. The cells death rate was evaluated by the quantification of the release of lactate dehydrogenase (LDH). LDH content was determined using LDH cytotoxicity assay kit (catalog \#: C0016, Beyotine Biotechnology, China), and the percentage of cells death rate was calculated as follows: [(experimental release - spontaneous release)/ (maximum release - spontaneous release)] $\times 100$. Spontaneous release and maximum release were obtained by incubating the cells alone or with a $0.1 \%$ Triton $\mathrm{x}-100$ solution respectively.

\section{Glucose consumption assay}

Cells were grown in 96 -well plates $\left(1 \times 10^{5}\right.$ cells per well) and treated with $0,1,10$ or $50 \mu \mathrm{M} \mathrm{(-)-HCA} \mathrm{for}$ $1,3,6,12$ or $24 \mathrm{~h}$. After incubation, $10 \mu \mathrm{L}$ of medium were collected from each well and glucose concentration was measured with a colorimetric glucose assay kit (catalog \#: F006) according to manufacturer's instruction (Jian Chen Biotechnology Institution, Nanjing, China). Glucose consumption was calculated as: non-cellular culture medium concentration - cellular culture medium concentration.

\section{Measurement of cellular mitochondrial respiration}

Mitochondrial oxygen consumption rate (OCR) was measured using a Seahorse XFe96 analyzer (Seahorse Bioscience). In brief, chicken hepatocytes were cultured in $\mathrm{XF}^{\mathrm{e}} 96$ cell culture microplate $\left(5 \times 10^{5}\right.$ cells per well) and treated with $0,1,10$ or $50 \mu \mathrm{M}(-)$-HCA for $24 \mathrm{~h}$. Oligomycin $(1 \mu \mathrm{M})$, FCCP (2-[2-[4-(trifluoromethoxy) phenyl] hydrazinylidene] - propanedinitrile) $(1 \mu \mathrm{M})$, and rotenone $(0.5 \mu \mathrm{M})$ combined with antimycin $(0.5 \mu \mathrm{M})$ were injected sequentially through ports in the Seahorse Flux Park cartridges as previously reported. First, the basal oxygen consumption rate (basal respiration) was measured. Oligomycin inhibited ATP synthase activity, which consequently inhibited electron flux and revealed the 


\section{Cellular Physiology Cell Physiol Biochem 2017;43:812-831 and Biochemistry Published \begin{tabular}{l|l} 
DOI: 10.1159/000481564 & (c)17 The Author(s). Published by S. Karger AG, Basel \\
www.karger.com/cpb
\end{tabular}}

Li et al.: Impact of (-)-HCA On Lipid Metabolism and Energy Metabolism

state of the coupling efficiency. FCCP uncoupled the respiratory chain and revealed the maximal capacity for reducing oxygen. The spare respiratory capacity was calculated by subtracting the basal respiration from the maximal respiration. Finally, rotenone combined with antimycin A was injected to inhibit the flux of electrons through complexes I and III; the remaining oxygen consumption rate was primarily due to nonmitochondrial respiration.

\section{Measurement of triglyceride content}

Cells were cultured in 6 -well plates $\left(2 \times 10^{6}\right.$ cells per well) and treated with $0,1,10$ or $50 \mu \mathrm{M}(-)$ HCA for 1, 3, 6, 12 or $24 \mathrm{~h}$. The cells were harvested and the triglyceride (TG) content (catalog \#: A1001) was analyzed using a commercial assay kit from Jian Chen Biotechnology Institution (Nanjing, China) and the data were normalized to the protein concentration determined using the BCA assay kit (Beyotime Biotechnology, China).

\section{Oil Red $O$ staining}

Cells were cultured in 6 -well plates $\left(2 \times 10^{6}\right.$ cells per well) and treated with $0,1,10$ or $50 \mu \mathrm{M}(-)$-HCA for $1,3,6,12$ or $24 \mathrm{~h}$. Oil Red 0 staining was performed according to the methods previously described [44]. Briefly, the cells were fixed with $10 \%$ buffered formalin for at least $30 \mathrm{~min}$. The cells were then incubated with $60 \%$ isopropanol for $15 \mathrm{~min}$ at room temperature and stained with oil red 0 solution for another 15 min. Cells were washed 4 times with deionized water and then allowed to air dry. To normalize the cell number, the cell were stained with hematoxylin for $5 \mathrm{~min}$ after Oil Red 0 staining. The slides were photographed with an optical microscope (Olympus BX53; Tokyo, Japan). Twenty photos were randomly selected from each group and ten independent visual field of each photo were used to analyze the counts and area of lipid droplets using Image-pro Plus 6.0 software (Media Cybernetics, Silver Spring, MD, USA).

\section{Determination of mRNA levels of lipid metabolism-related factors gene by Real-time quantitative RT-PCR} (qPCR)

Cells were cultured in 6 -well plates $\left(2 \times 10^{6}\right.$ cells per well) and treated with $0,1,10$ or $50 \mu \mathrm{M}(-)$-HCA for $1,3,6,12$ or $24 \mathrm{~h}$. The cells were harvested and total RNA was extracted from cultured cells using the TRIZOL reagent kit (Invitrogen, USA) according to the manufacturer's protocol. Total RNA ( $2 \mu \mathrm{g}$ ) were reverse transcribed into cDNA using the Superscript II kit (Promega, USA), according to the manufacturer's recommendation. An aliquot of complementary DNA sample was mixed with $20 \mu \mathrm{L}$ SYBR Green PCR Master Mix (Roche, Switzerland) in the presence of $10 \mathrm{pmol}$ of each forward and reverse primers for $\beta$-actin (use as an internal control), acetyl CoA carboxylase (ACC), fatty acid synthase (FAS), ATP-citrate lyase (ACLY), sterol regulatory element binding protein-1c $(S R E B P-1 c)$, peroxisome proliferators-activated receptor $\alpha(P P A R \alpha)$ and carnitine palmitoyl transferase-I (CPT-I) (Table 1). All samples were analyzed in duplicate using the IQ5 Sequence Detection System (Bio-Rad, California, USA) and programmed to conduct one cycle $\left(95^{\circ} \mathrm{C}\right.$ for $1 \mathrm{~min})$ and 40 cycles $\left(95^{\circ} \mathrm{C}\right.$ for $20 \mathrm{~s}, 60{ }^{\circ} \mathrm{C}$ for $30 \mathrm{~s}$ and $72{ }^{\circ} \mathrm{C}$ for $\left.30 \mathrm{~s}\right)$. Fold change were calculated using

Table 1. Prime sequence of targeted genes and $\beta$-actin

\begin{tabular}{|c|c|c|c|c|}
\hline Gene & $\begin{array}{c}\text { GenBank acession } \\
\text { number }\end{array}$ & Primer sequences $\left(5^{\prime}-3^{\prime}\right)$ & Orientation & Product size (bp) \\
\hline$\beta$-actin & L08165 & $\begin{array}{l}\text { TGCGTGACATCAAGGAGAAG } \\
\text { TGCCAGGGTACATTGTGGTA }\end{array}$ & $\begin{array}{l}\text { Forward } \\
\text { Reverse }\end{array}$ & 300 \\
\hline ACC & J03541 & $\begin{array}{l}\text { GTTGTGGTTGGCAGAGCAAG } \\
\text { GCACCAAACTTGAGCACCTG }\end{array}$ & $\begin{array}{l}\text { Forward } \\
\text { Reverse }\end{array}$ & 284 \\
\hline FAS & NM205155 & $\begin{array}{l}\text { TGAAGGACCTTATCGCATTGC } \\
\text { GCATGGGAAGCATTTTGTTGT }\end{array}$ & $\begin{array}{l}\text { Forward } \\
\text { Reverse }\end{array}$ & 96 \\
\hline ACLY & AJ851548 & $\begin{array}{l}\text { CACCCAGAGGTGGATGTTCT } \\
\text { GTTGCAGGCCCAATGTTAGT }\end{array}$ & $\begin{array}{l}\text { Forward } \\
\text { Reverse }\end{array}$ & 188 \\
\hline SREBP-1c & AY029224 & $\begin{array}{l}\text { GTCGGCGATCCTGAGGAA } \\
\text { CTCTTCTGCACGGCCATCTT }\end{array}$ & $\begin{array}{l}\text { Forward } \\
\text { Reverse }\end{array}$ & 105 \\
\hline $\operatorname{PPAR} \alpha$ & AF470455 & $\begin{array}{l}\text { CAAACCAACCATCCTGACGAT } \\
\text { GGAGGTCAGCCATTTTTTGGA }\end{array}$ & $\begin{array}{l}\text { Forward } \\
\text { Reverse }\end{array}$ & 64 \\
\hline CPT-I & AY675193 & $\begin{array}{l}\text { GGGTTGCCCTTATCGTCACA } \\
\text { TACAACATGGGCTTCCGTCC }\end{array}$ & $\begin{array}{c}\text { Forward } \\
\text { Reverse }\end{array}$ & 151 \\
\hline
\end{tabular}




\section{Cellular Physiology Cell Physiol Biochem 2017;43:812-831

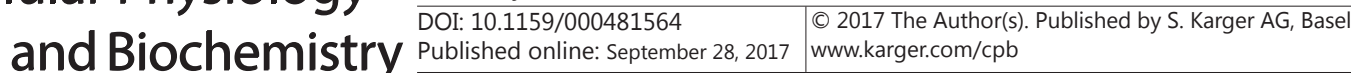

Li et al.: Impact of (-)-HCA On Lipid Metabolism and Energy Metabolism

the $2^{-\Delta \Delta \mathrm{CT}}$ method, and the relative amount of mRNA for each target gene was determined by calculating the ratio between each mRNA and the mRNA of $\beta$-actin. The primers used were designed with Primes Premier 5 (Premier Biosoft International, Palo Alto, CA, USA) and synthesized by Invitrogen Biological Company (Shanghai, China).

\section{Measurement of glycogen content}

Cells were cultured in 6-well plates $\left(2 \times 10^{6}\right.$ cells per well) and treated with $0,1,10$ or $50 \mu \mathrm{M}(-)$-HCA for $24 \mathrm{~h}$. The cells were harvested and the glycogen content (catalog \#: A043) was measured using commercial kits according to the manufacturers' protocols (Jiancheng Biotechnology Institution, Nanjing, China). The data was normalized to the sample protein content as determined by a BCA assay kit.

\section{Measurement of the key glucose metabolic enzyme protein content}

Cells were cultured in 6 -well plates $\left(2 \times 10^{6}\right.$ cells per well) and treated with $0,1,10$ or $50 \mu \mathrm{M}(-)$-HCA for $24 \mathrm{~h}$. The cells were harvested and disrupted ultrasonically in ice and then centrifuged at $3000 \mathrm{rpm}$ for 20 min at $4{ }^{\circ} \mathrm{C}$. The supernatants were collected, the protein concentrations of glycogen phosphorylase (GP) (catalog \#: E-75175), glycogen synthase (GS) (catalog \#: E-75174), glucokinase (GK) (catalog \#: E-76111), phosphofructokinase-1 (PFK-1) (catalog \#: E-76131), pyruvate kinase (PK) (catalog \#: E-76565), pyruvate dehydrogenase (PDH, E1) (catalog \#: E-76118), citrate synthase (CS) (catalog \#: E-75165), aconitase (ACO) (catalog \#: E-75144) and phosphoenolpyruvate carboxykinase (PEPCK) (catalog \#: E-75117) were measured using ELISA kits according to the manufactures' protocols (Shanghai Hengyuan Biological Technology Co., China). The enzyme protein content was normalized to total protein concentration in the sample.

\section{Measurement of the activity of succinate dehydrogenase and malate dehydrogenase}

Cells were cultured in 6 -well plates $\left(2 \times 10^{6}\right.$ cells per well) and treated with $0,1,10$ or $50 \mu \mathrm{M}(-)$-HCA for $24 \mathrm{~h}$. The cells were harvested and the activities of succinate dehydrogenase (SDH) (catalog \#: A022), malate dehydrogenase (MDH) (catalog \#: A021) were measured using commercial kits according to the manufacturers' protocols (Jiancheng Biotechnology Institution, Nanjing, China). The enzymes activity was normalized to the protein content in the sample and expressed as $\mathrm{U} / \mathrm{mg}$ protein.

\section{Determination of ATP-citrate (ACLY) and acetyl-CoA content}

Cells were cultured in 6 -well plates $\left(2 \times 10^{6}\right.$ cells per well) and treated with $0,1,10$ or $50 \mu \mathrm{M}(-)$-HCA for $24 \mathrm{~h}$. A half of cells were harvested and disrupted ultrasonically in ice and then centrifuged at $3000 \mathrm{rpm}$ for $20 \mathrm{~min}$ at $4{ }^{\circ} \mathrm{C}$, the supernatants were collected and the protein concentration of ATP-citrate (ACLY) (catalog \#: E-75166) was measured using an ELISA kit according to the manufactures' protocols (Shanghai Hengyuan Biological Technology Co., China). The other half of the cells were isolated the hepatocyte mitochondria by differential centrifugation as described by Lescuyer et al [45]. Briefly, the cells were harvested and disrupted ultrasonically for $1 \mathrm{~min}$ in $500 \mu \mathrm{L}$ homogenization buffer $(0.25 \mathrm{M}$ sucrose, $0.15 \mathrm{M} \mathrm{KCl}, 10 \mathrm{mM}$ Tris-Cl, pH 7.5, $1 \mathrm{mM}$ EDTA, $0.5 \%$ fatty acid-free BSA). The cell was then centrifuged for $10 \mathrm{~min}$ at $800 \mathrm{~g}$. The supernatants were collected and divided into two equal parts. One part of the suspension was used to determine the total content of acetyl-CoA. Another part of the suspension was centrifuged for $15 \mathrm{~min}$ at $12000 \mathrm{~g}$, and the supernatants were collected and detected the acetyl-CoA content in the cytosol. The acetyl-CoA (catalog \#: E-73218) concentration was determined by an ELISA kit according to the manufactures' protocol (Shanghai Hengyuan Biological Technology Co., China), and the data were normalized to the protein concentration as determined by a protein assay kit.

\section{Quantitation of mitochondria}

Cells were cultured in 6-well plates $\left(2 \times 10^{6}\right.$ cells per well) and treated with $0,1,10$ or $50 \mu \mathrm{M}(-)$-HCA for $48 \mathrm{~h}$. The cells were fixed in $0.1 \mathrm{M}$ sodium phosphate ( $\mathrm{pH} 7.4$ ) containing $2.5 \%$ glutaraldehyde, centrifuged at $3000 \mathrm{rpm}$ for $4 \mathrm{~min}$, and rinsed in the same buffer and post-fixed in 1\% osmium tetroxide in Millonig's buffer. Cell samples were then processed by standard techniques for transmission electron microscopy (TEM). Ultra-thin sections were stained with uranyl acetate and lead citrate and viewed in an H-7650 transmission electron microscope (Hitachi Company, Japan). The number of mitochondria was counted in fifteen independent cells from thirty photos randomly selected in each group. The results were tabulated as the mean number of mitochondria per cell for all treatment groups, and the method used in this study was modified from shen et al. [46]. 
Assessment complex $I$ and complex $V$ activities of mitochondrial respiratory chain

Cells were cultured in 6-well plates $\left(2 \times 10^{6}\right.$ cells per well $)$ and treated with $0,1,10$ or $50 \mu \mathrm{M}(-)$ HCA for $24 \mathrm{~h}$. The cells were harvested and disrupted ultrasonically in ice and then centrifuged at $3000 \mathrm{rpm}$ for $20 \mathrm{~min}$ at $4{ }^{\circ} \mathrm{C}$. The supernatants were collected. The protein concentration of NADH dehydrogenase (catalog \#: E-75714) and ATP synthase (catalog \#: E-75448) were measured using ELISA kits according to the manufactures' protocols (Shanghai Hengyuan Biological Technology Co., China). The NADH dehydrogenase and ATP synthase protein content were used to represent the activity of complex I and complex $\mathrm{V}$ of mitochondrial respiratory chain.

Data analysis and statistics

Data were analyzed with one-way ANOVA and expressed as the means \pm the standard error of the mean (SEM). Treatment differences were subjected to a Duncan's multiple comparison tests. Differences were considered significant at $\mathrm{P}<0.05$. All statistical analyses were performed with SPSS 20.0 for Windows (StatSoft, Inc., Tulsa, OK, USA).

\section{Results}

Effect of (-)-HCA on cell
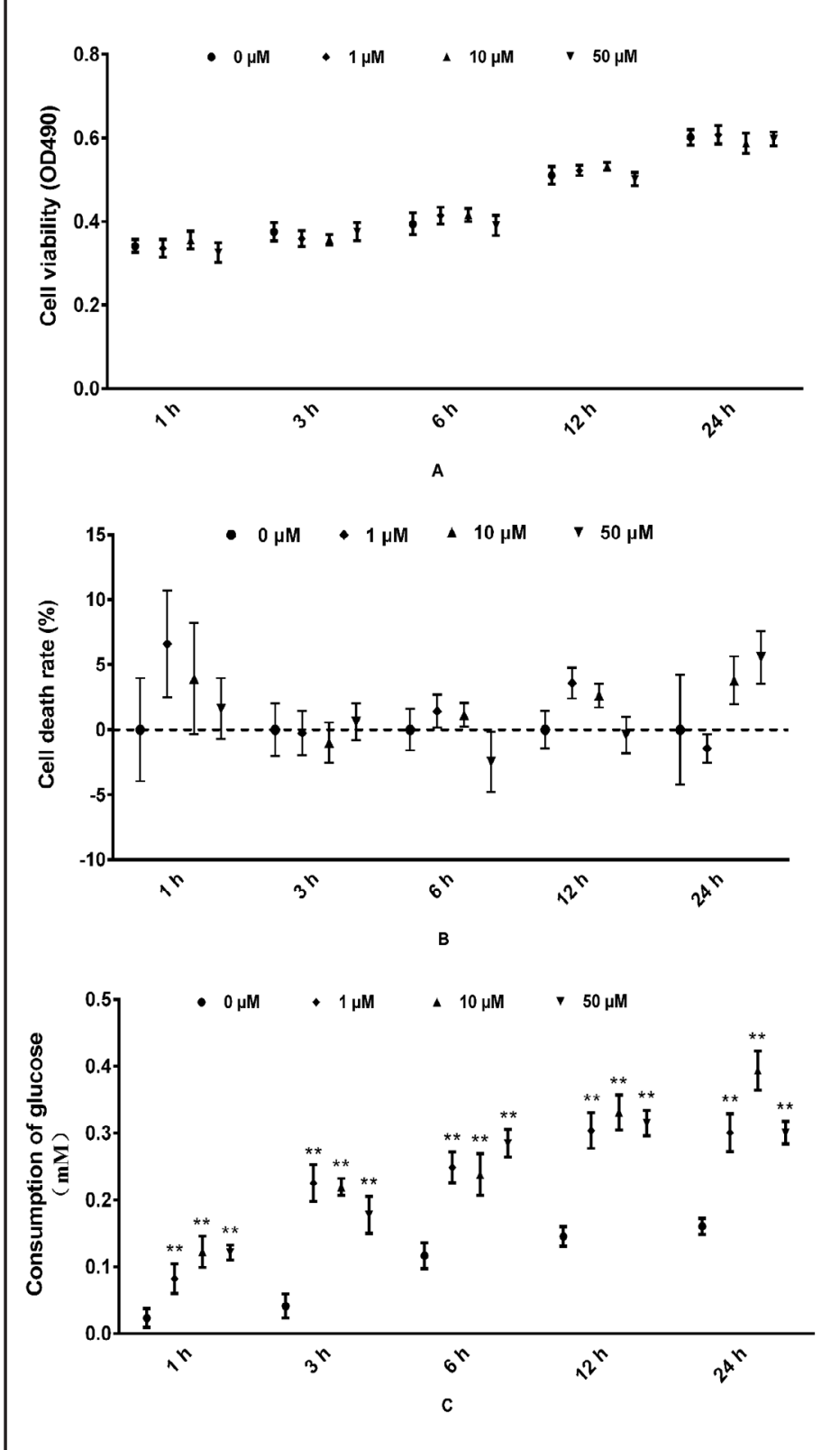

Fig. 1. Effect of (-)-HCA on cell viability, cell death rate and consumption of glucose in primary chicken hepatocytesA: Cell viability; B: Cell death rate; $\mathrm{C}$ : consumption of glucose. Values are means $\pm \mathrm{SE},{ }^{* *} \mathrm{P}<0.01$ and ${ }^{*} \mathrm{P}<0.05$, compared to control group at the same time point.

viability, cell death rate

and glucose consumption in cultured primary chicken hepatocytes

No significant differences were observed in cells viability in all (-)-HCA treated groups when compared to the control group from 1 to $24 \mathrm{~h}(P>0.05)$ (Fig. 1A). Furthermore, the cells death rate was not affected by (-)-HCA treatment when compared to the control group at different time period $(P>0.05)$ (Fig. 1B). The consumption of glucose was significantly increased in 1-50 $\mu \mathrm{M}(-)$-HCA treated groups than that in control group from 1 to $24 \mathrm{~h}(P<$ 0.01) (Fig. 1C). 
Fig. 2. Effect of (-)-HCA on mitochondrial respiration in primary chicken hepatocytesA: Mitochondrial respiration measurements of OCR was performed with a Seahorse metabolic analyzer. Oligomycin $(1 \mu \mathrm{M})$, FCCP $(1 \mu \mathrm{M})$, and rotenone $(0.5 \mu \mathrm{M})$ combined with antimycin $(0.5 \mu \mathrm{M})$ were added sequentially to hepatocytes treated with (-)-HCA. B: cellular respiration parameters (basal respiration, maximal respiration, spare respiratory capacity and non-mitochondrial respiration). Values are means $\pm \mathrm{SE}$. ${ }^{* *} \mathrm{P}<0.01$ and ${ }^{*} \mathrm{P}<0.05$, compared to control group at the same time point.
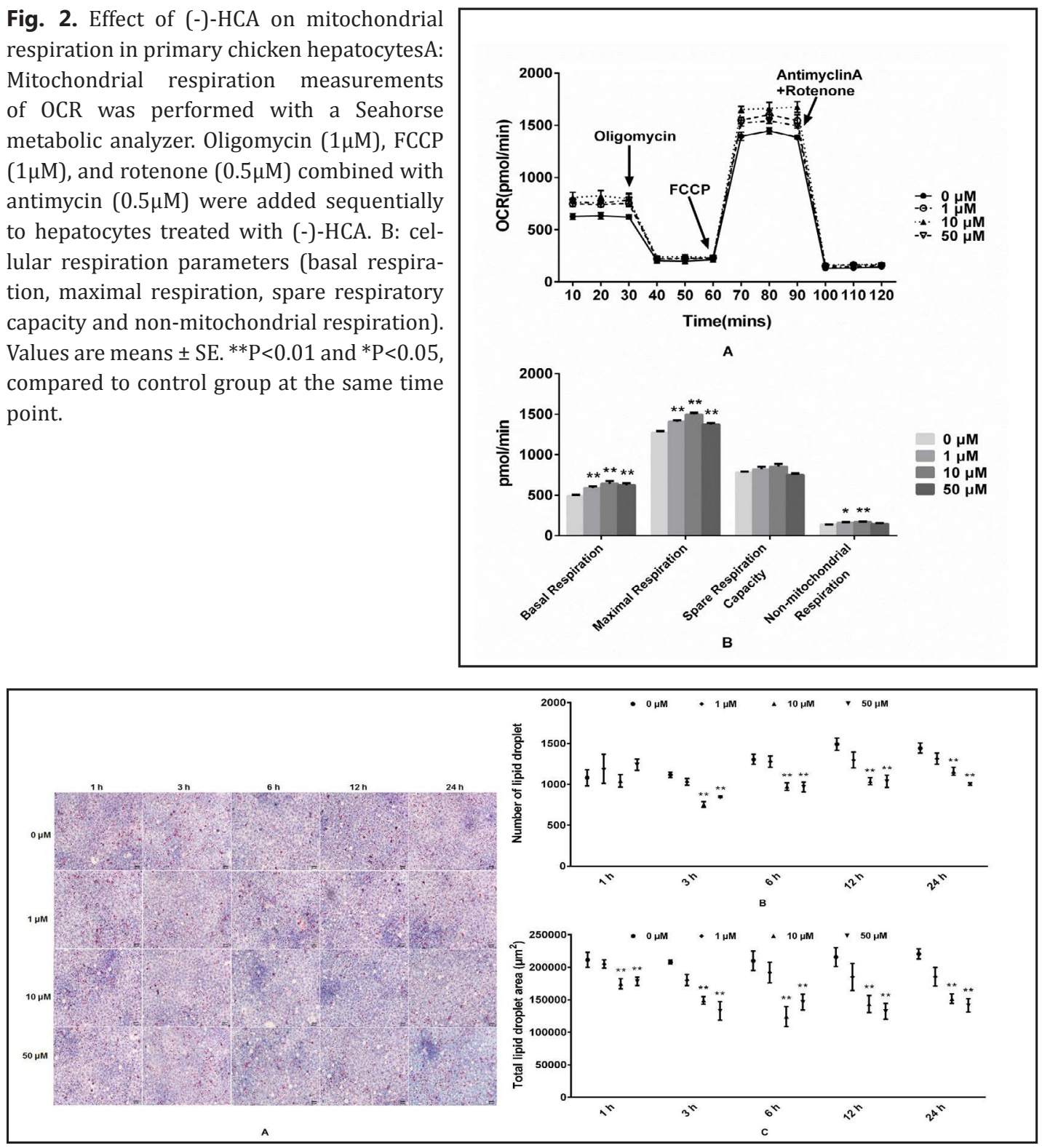

Fig. 3. Representative photomicrographs of hepatocytes stained with oil red 0 in primary chicken hepatocytes treated with (-)-HCAA: Representative photomicrographs of oil red 0 staining; B: Number of lipid droplets; C: Total area of lipid droplets. Values are means $\pm \mathrm{SE}$. ${ }^{* *} \mathrm{P}<0.01$ and ${ }^{*} \mathrm{P}<0.05$, compared to control group at the same time point.

Effect of (-)-HCA on mitochondrial respiration in cultured primary chicken hepatocytes

Oxygen consumption rate (OCR) of hepatocytes utilizing glucose as substrate after (-)-HCA treatment was analyzed using a Seahorse XFe96 instrument (Fig. 2A). The results showed that (-)-HCA treatment significantly increased basal OCR, maximal OCR and nonmitochondrial OCR $(P<0.01)$, but has no significant differences in spare respiration capacity (Fig. 2B).

Effect of (-)-HCA on lipid droplet accumulation and triglyceride content in cultured primary chicken hepatocytes

To analyze the distribution of lipid droplets in cells after (-)-HCA treated, Oil Red 0 staining (Fig. 3A) was used to analyze the counts and the total area of lipid droplets. Results 
Fig. 4. Effect of (-)-HCA on the triglyceride content in primary chicken hepatocytesValues are means \pm SE. ${ }^{* *} \mathrm{P}<0.01$ and $* \mathrm{P}<0.05$, compared to control group at the same time point.
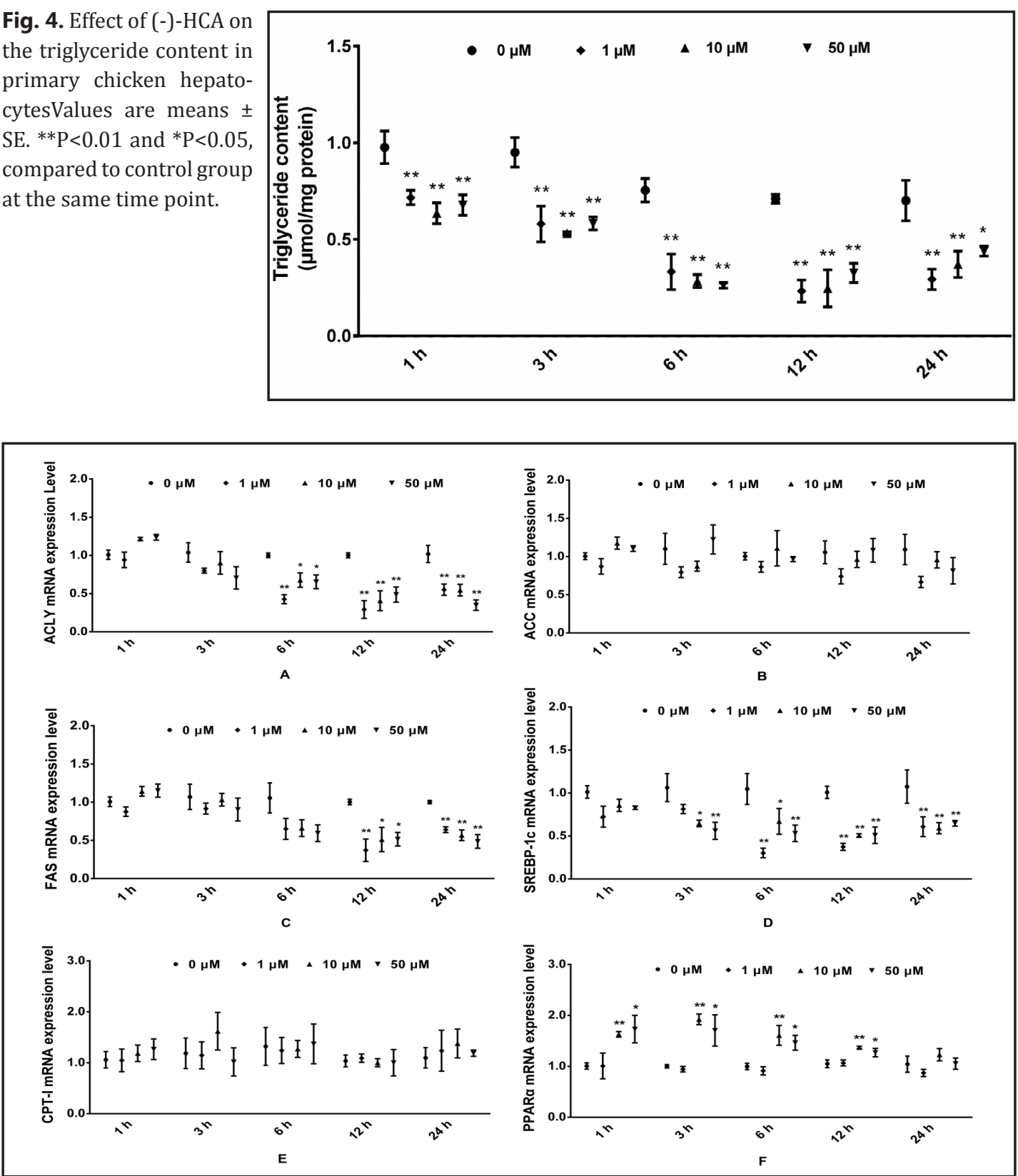

Fig. 5. Effect of (-)-HCA on lipid metabolism-related gene expression level in chicken hepatocytesA: ATP-citrate lyase (ACLY) mRNA expression level; B: Acetyl CoA carboxylase (ACC) mRNA expression level; C: Fatty acid synthase (FAS) mRNA expression level; D: Sterol regulatory element binding protein-1c (SREBP-1c) mRNA expression level; E: Carnitine palmitoyl transferase-I (CPT-I) mRNA expression level; F: Peroxisome proliferators-activated receptor $\alpha(\mathrm{PPAR} \alpha)$ mRNA expression level. Values are means $\pm \mathrm{SE}, * * \mathrm{P}<0.01$ and ${ }^{*} \mathrm{P}<0.05$, compared to control group at the same time point.

showed that the numbers of lipid droplet (Fig. 3C) were significantly decreased in 10 and 50 $\mu \mathrm{M}(-)$-HCA treated groups than that in the control group from 3 to $24 \mathrm{~h}$ (Fig. 3B) $(P<0.01)$. Similarly, 10 and $50 \mu \mathrm{M}(-)$-HCA treatment significantly decreased the total area of lipid droplet when compared to the control group during the experimental period from 1 to 24 $\mathrm{h}(P<0.01)$ (Fig. 3C). Biochemical analysis results showed that 1- $50 \mu \mathrm{M}(-)$-HCA treatment significantly reduced triglyceride content when compared to the control group from 1 to 24 h $(P<0.01)$ (Fig. 4). 
Fig. 6. Effect of (-)-HCA on the ATP-citrate lyase protein content in primary chicken hepatocytesValues are means $\pm \mathrm{SE}$. ${ }^{*} \mathrm{P}<0.01$ and $* \mathrm{P}<0.05$, compared to control group.
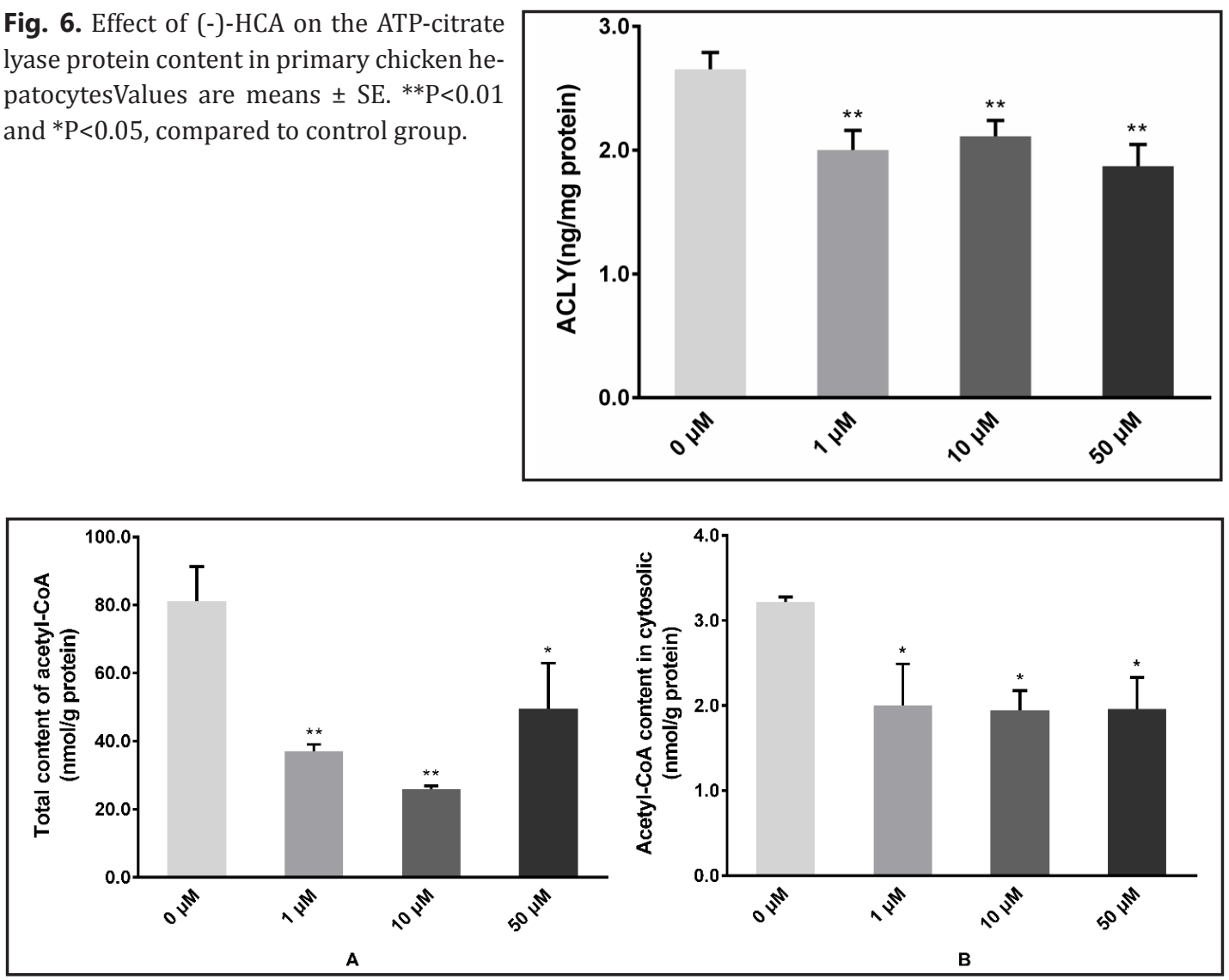

Fig. 7. Effect of (-)-HCA on acetyl-CoA content in primary chicken hepatocytes A: Total content of acetylCoA; B: Acetyl-CoA content in cytosol. Values are means \pm SE. ${ }^{*} \mathrm{P}<0.01$ and ${ }^{*} \mathrm{P}<0.05$, compared to control group.

Effect of (-)-HCA on lipid metabolism-related gene expression in cultured primary chicken hepatocytes

A significant decrease was found on the $A C L Y$ mRNA level when cells were treated with 1-50 $\mu \mathrm{M}(-)$-HCA for 6-24 h $(P<0.05)$ (Fig. 5A), while no differences were found on the ACC mRNA level in cultured primary hepatocytes treated with various concentrations of (-)-HCA at different time points (Fig. 5B) $(P>0.05)$. FAS mRNA level was decreased in 1-50 $\mu \mathrm{M}(-)-$ HCA treated groups from 12 to $24 \mathrm{~h}$ when compared to the control group $(P<0.05)$ (Fig. 5C). $S R E B P-1 c$ mRNA levels (3 to $24 \mathrm{~h}$ ) were significantly decreased after (-)-HCA treatment than that in the control group $(P<0.05)$, except for the $1 \mu \mathrm{M}(-)$-HCA treated group at $3 \mathrm{~h}(P>$ 0.05 ) (Fig. 5D). There was no noticeable response to (-)-HCA treatment in CPT-I mRNA level $(P>0.05)$ (Fig. 5E), while PPAR $\alpha$ mRNA level was significantly increased in $10 \mu \mathrm{M}$ or $50 \mu \mathrm{M}$ $(-)$-HCA treated groups than those in the control group during the experimental period from 1 to $12 \mathrm{~h}(P<0.05)$ (Fig. 5F).

Effect of (-)-HCA on ATP-citrate lyase and acetyl-CoA content in cultured primary chicken hepatocytes

As shown in Fig. 6, the ATP-citrate (ACLY) protein content in all (-)-HCA treated groups were significantly decreased than that in the control group $(P<0.01)$. Total acetyl-CoA contents were significantly decreased in 1-50 $\mu \mathrm{M}(-)$-HCA treated groups than that in the control group $(P<0.05)$ (Fig.7A). Meanwhile, $(-)$-HCA treated significantly decreased the acetyl-CoA content in the cytosol when compared to the control group $(P<0.05)$ (Fig. 7B). 


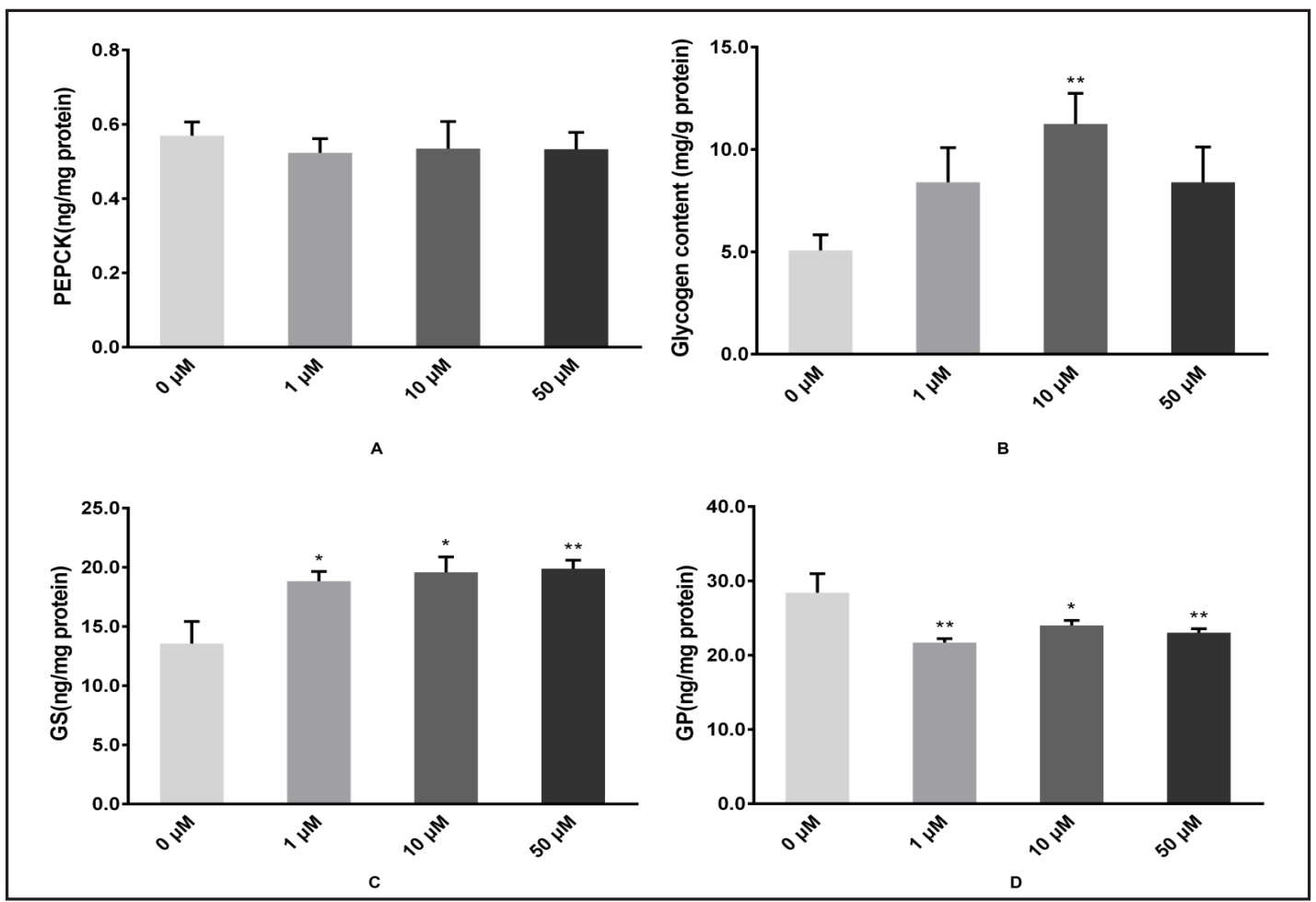

Fig. 8. Effect of (-)-HCA on gluconeogenesis and glycogen metabolism in primary chicken hepatocytesA: Phosphoenolpyruvate carboxykinase (PEPCK) protein content; B: Glycogen content; C: Glycogen synthase (GS) protein content; D: Glycogen phosphorylase (GP) protein content. Values are means $\pm \mathrm{SE} .{ }^{* *} \mathrm{P}<0.01$ and ${ }^{*} \mathrm{P}<0.05$, compared to control group.

Effect of (-)-HCA on gluconeogenesis and glycogen metabolism in cultured primary chicken hepatocytes

No significant differences were observed on the protein content of phosphoenolpyruvate carboxykinase (PEPCK) in primary chicken hepatocytes treated with $(-)$-HCA $(P>0.05)$ (Fig. $8 \mathrm{~A})$. Glycogen content was significantly higher in $10 \mu \mathrm{M}(-)-\mathrm{HCA}$ treated group than that in the control group $(P<0.01)$ (Fig. 8B). Compared with the control group, $(-)$-HCA treated significantly increased glycogen synthase protein content in cultured primary chicken hepatocytes $(P<0.05)$ (Fig. 8C). However, glycogen phosphorylase protein content was significantly decreased in 1-50 $\mu \mathrm{M}(-)$-HCA treated group than that in the control group $(P<$ 0.05) (Fig. 8D).

Effect of (-)-HCA on glucose catabolism in cultured primary chicken hepatocytes

Compared with the control group, 1-50 $\mu \mathrm{M}(-)$-HCA significantly increased the contents of GK and PFK-1 in cultured primary chicken hepatocytes $(P<0.05)$ (Fig. 9A and 9B). The PK protein content was significantly increased in $10 \mu \mathrm{M}$ and $50 \mu \mathrm{M}(-)$-HCA treated groups when compared with those in the control group $(P<0.01)$ (Fig. 9C). 1-50 $\mu \mathrm{M}(-)$-HCA treatment significantly increased the protein contents of PDH (E1), CS and ACO when compared to the control group $(P<0.05)$ (Fig. 9D, 9E and 9F). In addition, we found that the activities of SDH and MDH was significantly increased in $10 \mu \mathrm{M}$ and $50 \mu \mathrm{M}(-)$-HCA treated groups than that in the control group $(P<0.05)$ (Fig. 9G and 9H).

Morphological observations and quantization of mitochondrial in cultured primary chicken hepatocytes

Hepatocellular mitochondria were examined by electron microscopy. The histological organization of cultured primary chicken hepatocytes was not altered by 1-50 $\mu \mathrm{M}(-)$-HCA 

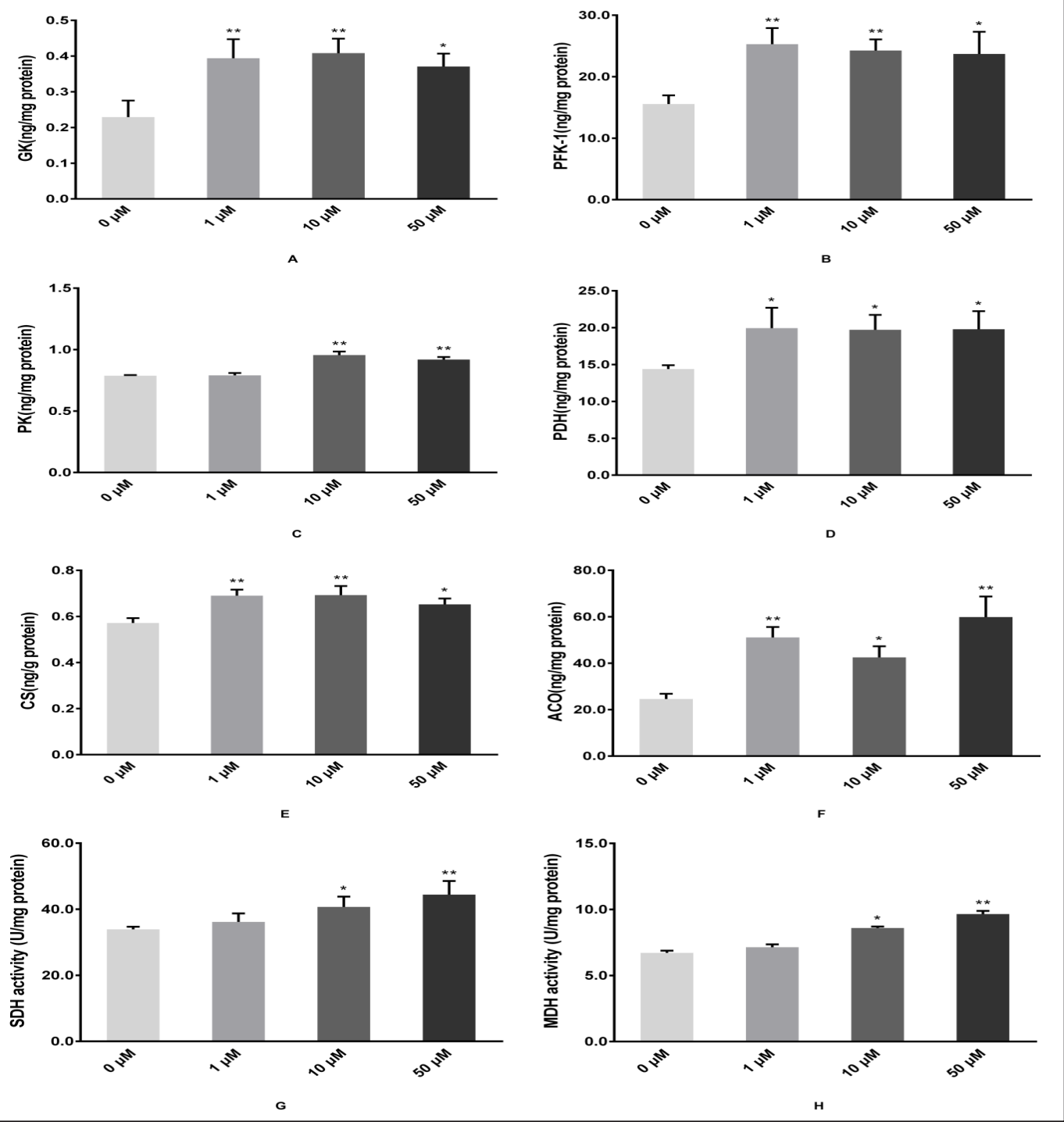

Fig. 9. Effect of (-)-HCA on the key enzyme protein content of glucose catabolism in primary chicken hepatocytesA: Glucokinase (GK) protein content; B: Phosphofructokinase-1 (PFK-1) protein content; C: Pyruvate kinase (PK) protein content; D: Pyruvate dehydrogenase (PDH, E1) protein content; E: Citrate synthase (CS) protein content; F: Aconitase (ACO) protein content; G: Succinate dehydrogenase (SDH) activity; Malate dehydrogenase $(\mathrm{MDH})$ activity. Values are means $\pm \mathrm{SE}$. ${ }^{* *} \mathrm{P}<0.01$ and ${ }^{*} \mathrm{P}<0.05$, compared to control group.

treatment when compared to the control group (Fig.10A). The number of mitochondria in fifteen independent cells from thirty randomly selected fields in each group were counted, no noticeable changes were observed in (-)-HCA treated groups compared with the control group (Fig. 10B) $(P>0.05)$.

Effect of (-)-HCA on complex I and complex V activities of mitochondrial respiratory chain in cultured primary chicken hepatocytes

As shown in Fig. 11A, 1-50 $\mu \mathrm{M}(-)-H C A$ significantly increased NADH dehydrogenase protein content when compared with the control group in cultured primary chicken hepatocytes $(P<0.05)$. Similar, ATP synthase protein content was significantly increased after $(-)$-HCA treatment $(P<0.01)$ (Fig. 11B). 


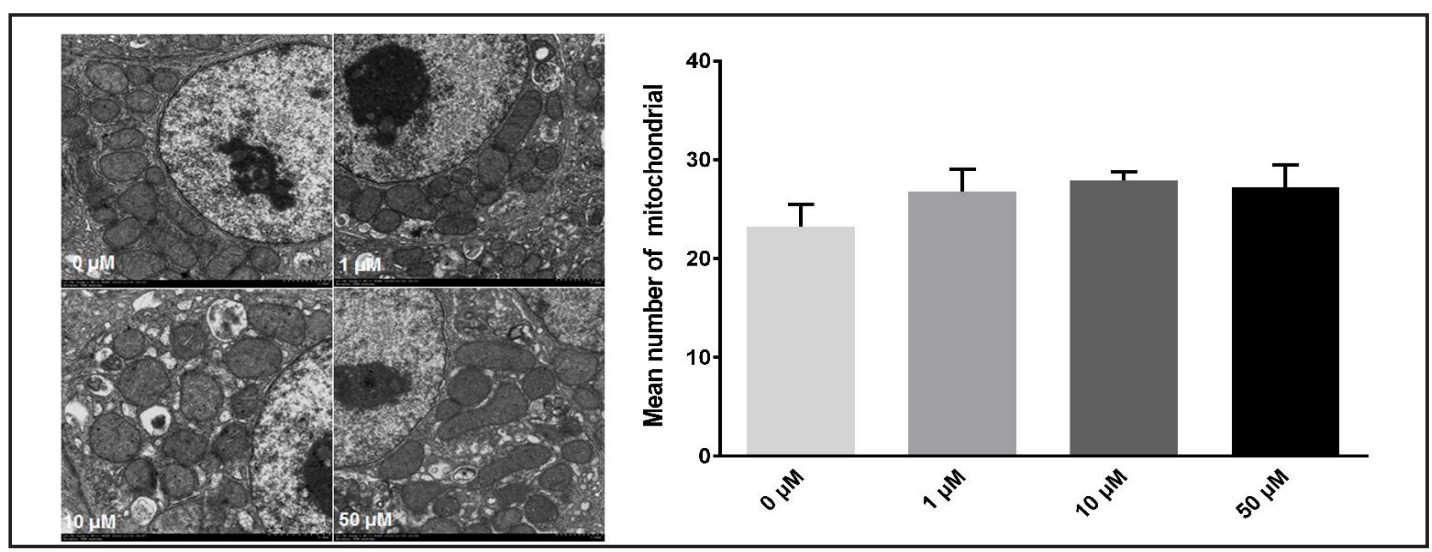

Fig. 10. Electron micrographs and the number of mitochondria in primary chicken hepatocytes treated with (-)-HCAA: Electron micrographs; B: Number of mitochondria. After incubation, cell samples were processed by standard techniques for transmission electron microscopy, and ultra-thin sections were observed with magnification $\times 2500$. Thirty photos were randomly selected from each group, and the number of mitochondria was counted in 15 independent cells of each photo. The results are displayed as the mean number of mitochondria per cell in all treatment groups.

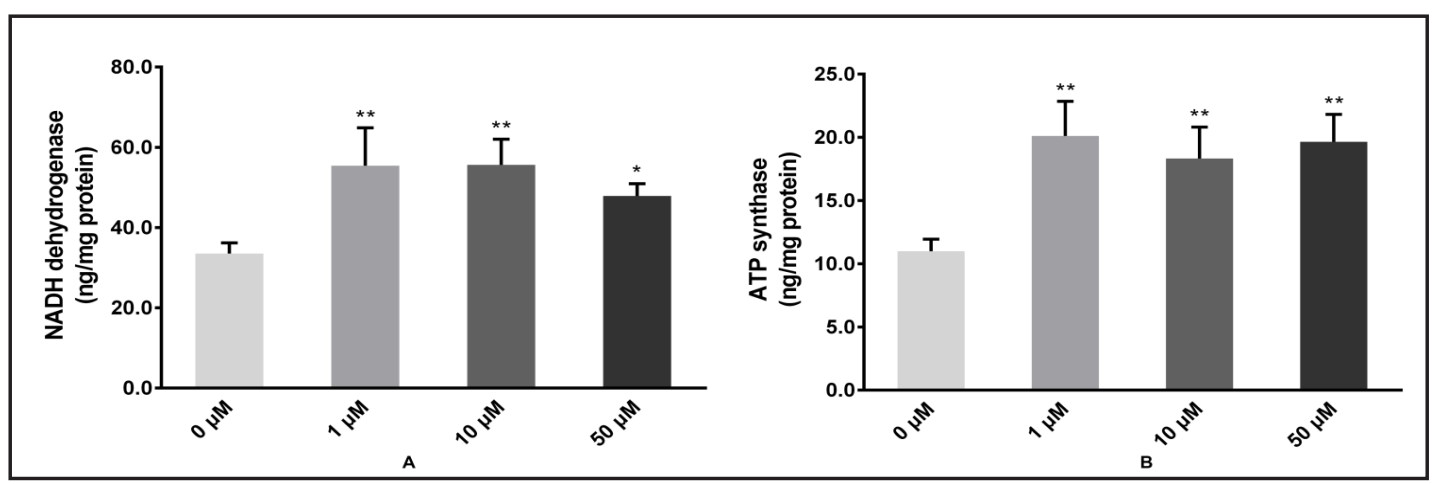

Fig. 11. Effect of (-)-HCA on complex I and complex V activity of mitochondrial respiratory chain in primary chicken hepatocytesA: NADH dehydrogenase protein content; B: ATP synthase protein content. Values are means $\pm \mathrm{E}$. ${ }^{* *} \mathrm{P}<0.01$ and ${ }^{*} \mathrm{P}<0.05$, compared to control group.

\section{Discussion}

$(-)$-Hydroxycitric acid (HCA) is widely used as an ingredient for a nutritional supplement to control body weight gain and inhibit fat accumulation in humans [23, 47-49] and animals $[25,50,51] .(-)$-HCA-containing products have been on the market for many years $[18$, 27]. A number of reports demonstrated the efficacy of extracts from Garcinia cambogia or $(-)$-HCA were found in animals [18, 52-54] and humans [55-57]. The liver is the primary site of metabolism in poultry [35]. To evaluate whether (-)-HCA had an adverse effect on hepatocyte, the cell viability and cell death rate after (-)-HCA treatment was measured using the MTT assay and LDH test. Our results showed that no differences were observed in cell survival and cell death rate in cultured primary chicken hepatocytes treatment with (-)-HCA. The result was consistent with the result of Nisha et al., who reported that (-)-HCA did not cause significant cell death up to $100 \mu \mathrm{M}$ in 3T3-L1 adipocytes [58]. Therefore, we presumed that (-)-HCA treatment up to $50 \mu \mathrm{M}$ was safe in primary chicken hepatocytes.

Many studies had found that (-)-HCA administration reduces fat accumulation in chickens $[59,60]$, rodents $[32,61,62]$ and humans $[51,63]$. Excess accumulation of lipids results in oxidative stress, mitochondrial dysfunction and obesity [64]. Lipid droplet accumulation is important for evaluating the overall lipid metabolic status [65]. Our results 
showed that (-)-HCA treatment significantly reduced the amount and total area of lipid droplets in cultured primary chicken hepatocytes. These results were consistent with the previous report which showed that Garcinia cambogia extracts significantly suppressed the adipogenic differentiation of pre-adipocytes and intracellular lipid accumulation in the differentiating adipocytes [66]. The previous study reported that the Garcinia cambogia extracts inhibits lipid droplet accumulation in fat cells without affecting adipose conversion in 3T3-L1 cells [67]. In addition, Kim et al. reported that Garcinia cambogia extracts inhibits the cytoplasmic lipid droplet accumulation as well as adipogenic differentiation of preadipocytes [68]. Consistent with the reduction of lipid droplet, our results showed that (-)HCA treated significantly decreased the triglyceride content in primary chicken hepatocytes. Our recent study showed that supplemental (-)-HCA inhibited lipogenesis and accelerated lipolysis, which eventually led to reduced abdominal fat deposition in broiler chickens [59]. These results demonstrated that (-)-HCA treatment suppress fatty acid synthesis in primary chicken hepatocytes.

Many studies have certified (-)-HCA as a competitive inhibition of ATP citrate-lyase (ACLY) which plays a crucial role in the fatty acid synthesis $[25,26,31,50]$. The present study showed that (-)-HCA treatment significantly decreased the ACLY mRNA level in primary chicken hepatocytes. ACLY catalyzes the extra-mitochondrial cleavage of citrate to oxaloacetate and acetyl-CoA in cytosol; acetyl-CoA were catalyzed by acetyl-CoA carboxylase (ACC) and fatty acid synthase (FAS) for the fatty acid synthesis. Although no difference was observed on the ACC mRNA level in our study, supplement of (-)-HCA markedly decreased FAS mRNA level in primary chicken hepatocytes from 12 to $24 \mathrm{~h}$. In addition, we found that SREBP-1C mRNA level was lower in primary chicken hepatocytes after treated with $(-)$-HCA. SREBP have been described as the regulator of biosynthesis of cholesterol and fatty acids in the liver $[69,70]$. SREBP-1c can directly stimulate the transcription of genes encoding FAS enzymes [71, 72]. These results were consistent with our previous results that showed supplemental (-)-HCA inhibited lipogenesis by inhibiting ACLY, SREBP-1c and FAS expression which eventually led to reduced abdominal fat deposition in broiler chickens [59]. Fat accumulation is a complex process which depends on the balance of lipogenesis and lipolysis. It is hypothesized that (-)-HCA could increase fat oxidation via inhibiting malonylCoA formation, which would activate carnitine palmitoyl transferase-I (CPT-I) activity [21]. In the present study, (-)-HCA treatment significantly increased PPAR $\alpha$ mRNA level, while no noticeable changes were observed on the CPT-I mRNA level in primary chicken hepatocytes. It is well known that PPAR $\alpha$ is a member of the nuclear hormone receptor family of transcription factor and it can increase the rate of fatty acid $\beta$-oxidation by increasing the expression of several target genes, such as CPT-1 [73]. Considering the reduction of lipid droplet and decreasing of triglyceride content, it is possible that (-)-HCA treatment mainly inhibited fatty acids synthesis by decreasing lipogenesis-relative factors mRNA expression level rather than accelerating lipolysis, which eventually led to reduced fat deposition in primary chicken hepatocytes. Therefore, the significant changes of SREBP-1C, ACLY, and FAS mRNA level indicate that these genes might be directly responsible for the reduction of fat accumulation in primary chicken hepatocytes treated with (-)-HCA.

As mentioned above, several mechanisms of(-)-HCA actions are proposed and the primary mechanism appears to be related to its property as a potent competitive inhibitor of ATPcitrate lyase [30, 35, 50]. Our results showed that (-)-HCA treatment significantly inhibited the ACLY protein content in primary chicken hepatocytes. Furthermore, we found that the acetyl-CoA content of cytosol was significantly decreased in primary chicken hepatocytes treated with (-)-HCA. This results suggested that (-)-HCA treatment reduced acetyl-CoA content in cytosol mainly through inhibiting the ACLY activity, which would inhibited the lipogenesis-related factors, such as FAS and SREBP-1C expression, and eventually led to the reduced fat accumulation in primary chicken hepatocytes. The present study also found that total acetyl-CoA content was significantly decreased in primary chicken hepatocytes after (-)HCA treatment. In the body, the acetyl-CoA is mainly originated from the glucose metabolism or $\beta$-oxidation of fatty acids. Mitochondria provide the majority of cellular energy in the form 
of ATP through OXPHOS. The major metabolic processes, glycolysis and aerobic metabolism, provide energy for cells and can be studied by measuring oxygen consumption and glucose utilization. (-)-HCA treatment significantly increased the consumption of glucose and basal OCR in primary chicken hepatocytes. Based on these results, we hypothesized that (-)HCA might improve the utilization of glucose and aerobic metabolism in primary chicken hepatocytes.

No significant difference were observed on the phosphoenolpyruvate carboxykinase protein content in primary chicken hepatocytes after (-)-HCA treatment. In addition, the present study showed that glycogen content was increased in primary chicken hepatocytes treated with (-)-HCA. This result was consistent with our previous study that demonstrated that (-)-HCA significantly enhanced glycogen storage in broiler chickens [59]. It was reported that (-)-HCA treatment significantly promoted glucose conversion to glycogen in human [63]. In addition, (-)-HCA treatment significantly decreased glycogen phosphorylase (GP) protein content and increased glycogen synthase (GS) protein content in primary chicken hepatocytes. Glycogenesis and glycogenolysis during the diurnal cycle are mediated by glycogen synthase and glycogen phosphorylase, respectively [74]. Thus, these results indicated that (-)-HCA treatment enhanced glycogen storage by enhancing the glycogen synthase protein content and inhibiting glycogen phosphorylase protein content in primary chicken hepatocytes.

In the liver, glucokinase (GK) is a specific enzyme to the phosphorylation glucose to glucose 6-phosphate. Our results showed that (-)-HCA treatment significantly increased the glucokinase protein content in primary chicken hepatocytes. Depending on the energy requirement, the glucose 6-phosphate is channeled to glycogen synthesis or used for energy production by the glycolytic pathway [75]. Phosphofructokinase-1 (PFK-1) is one of the most important regulatory enzymes of glycolysis, which catalyzes the fructose-6-phosphate convert into fructose 1, 6-bisphosphate, is one of the key enzyme in the process of glycolysis. $\mathrm{PFK}$ is also able to regulate glycolysis through allosteric inhibition to regulate the rate of glycolysis in response to the cell's energy requirements [76]. Our results showed that PFK-1 protein content was significantly enhanced in primary chicken hepatocytes after (-)-HCA treatment. Furthermore, our results showed that pyruvate kinase, which catalyzes the final step in glycolysis, were significantly enhanced in primary chicken hepatocytes treated with (-)-HCA. The pyruvate dehydrogenase complex converts pyruvate into acetyl-CoA, which may then be used in the citric acid cycle for cellular respiration [77]. The reaction catalyzed by pyruvate dehydrogenase (E1) is considered to be the rate-limiting reaction in the pyruvate dehydrogenase complex $[77,78]$. The present results showed that (-)-HCA treatment significantly increased PDH (E1) protein content in primary chicken hepatocytes. This result was consistent with our study which revealed that supplemental with (-)-HCA increased the pyruvate dehydrogenase E1 component subunit alpha (PDHA1) and beta (PDHB) protein expression levels in the liver of broiler chickens [29]. The citric acid cycle is the start and end of many metabolic pathways, which are involved in carbohydrate, fat metabolism and protein metabolism $[79,80]$. Our results showed that the protein contents of citrate synthase, aconitase (ACO), and the activities of succinate dehydrogenase (SDH), malate dehydrogenase (MDH) were enhanced in primary chicken hepatocytes treated with $(-)$-HCA. It had been reported that ACO was upregulated in the liver of broiler chickens treated with (-)-HCA [29]. Some studies have shown that the expression of ACO protein is increased when the energy consumption is enhanced, which eventually accelerates the citric acid cycle [81]. MDH is an enzyme that reversibly catalyzes the oxidation of malate to oxaloacetate and this reaction is a part of many metabolic pathways [82]. In addition, SDH is a membrane-bound enzyme which is the only enzyme that participates in both the citric acid cycle and the electron transport chain [83]. Thus, we suspected that the effect of $(-)$-HCA on fat accumulation might be associated with the decrease of cytosolic acetyl-CoA level, which are required for fatty acid synthesis, through decreasing ACLY protein content and enhancing the key enzyme activity to accelerate glucose catabolism in primary chicken hepatocytes.

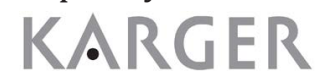


No noticeable difference was found on the number of mitochondria in primary chicken hepatocytes treated with (-)-HCA. Mitochondria are the place of cellular energy metabolism and its main function is to synthesize ATP to provide energy for all kinds of life activities. In addition, the present study showed that the SDH activity, which is the only enzyme that participates in both the citric acid cycle and the electron transport chain [83], was significantly increased in primary chicken hepatocytes after (-)-HCA treatment. Thus, we presumed that (-)-HCA treatment might enhance the function of mitochondrial respiratory chain in primary chicken hepatocytes. Our results showed that (-)-HCA treatment significantly increased the NADH dehydrogenase protein content in primary chicken hepatocytes. NADH dehydrogenase, the mainly component of Complex I, is the largest and most complicated enzyme in the electron transport chain [84]. Recently, we had certified that the NDUFS3, NDUFS8 and NDUFA10 protein expression levels were increased in the liver of broiler chickens after (-)-HCA supplementation [29]. NDUFS3 and NDUFA10 are important subunits of NADH dehydrogenase: NDUFS3 plays a vital role in the proper assembly of complex I [85], while NDUFA10 transfers electrons from NADH to ubiquinone in the respiratory chain [86]. Further, ATP synthase plays an important role in energy transduction, ATP synthesis catalyzed by ATP synthase is powered by the transmembrane electrochemical proton potential [87]. In this study, we found that (-)-HCA treatment significantly increased the ATP synthase protein content in primary chicken hepatocytes. This result was consistent with the result of Peng et al., which showed that (-)-HCA treatment increased the expression of ATP5H, a subunit of ATP synthase, in the liver of broiler chickens [29]. Based on the increase of NADH dehydrogenase and ATP synthase contents and succinate dehydrogenase activity, we assumed that (-)-HCA treatment might accelerate energy metabolism in primary chicken hepatocytes mainly through enhancing the function of respiratory chain. In addition, our previous study showed that supplemental (-)-HCA reduced abdominal fat deposition and enhanced glycogen content [59], and enhanced the expression of key proteins in carbohydrate

Fig. 12. Mechanism of (-)-HCA reduced lipid droplets accumulation in primary chicken hepatocytes(-)HCA inhibited fatty acid synthesis via the decrease in the supply of acetylCoA which was mainly achieved by inhibition the ATP-citrate lyase activity; it also accelerated glucose catabolism and energy metabolism. All of which eventually reduced

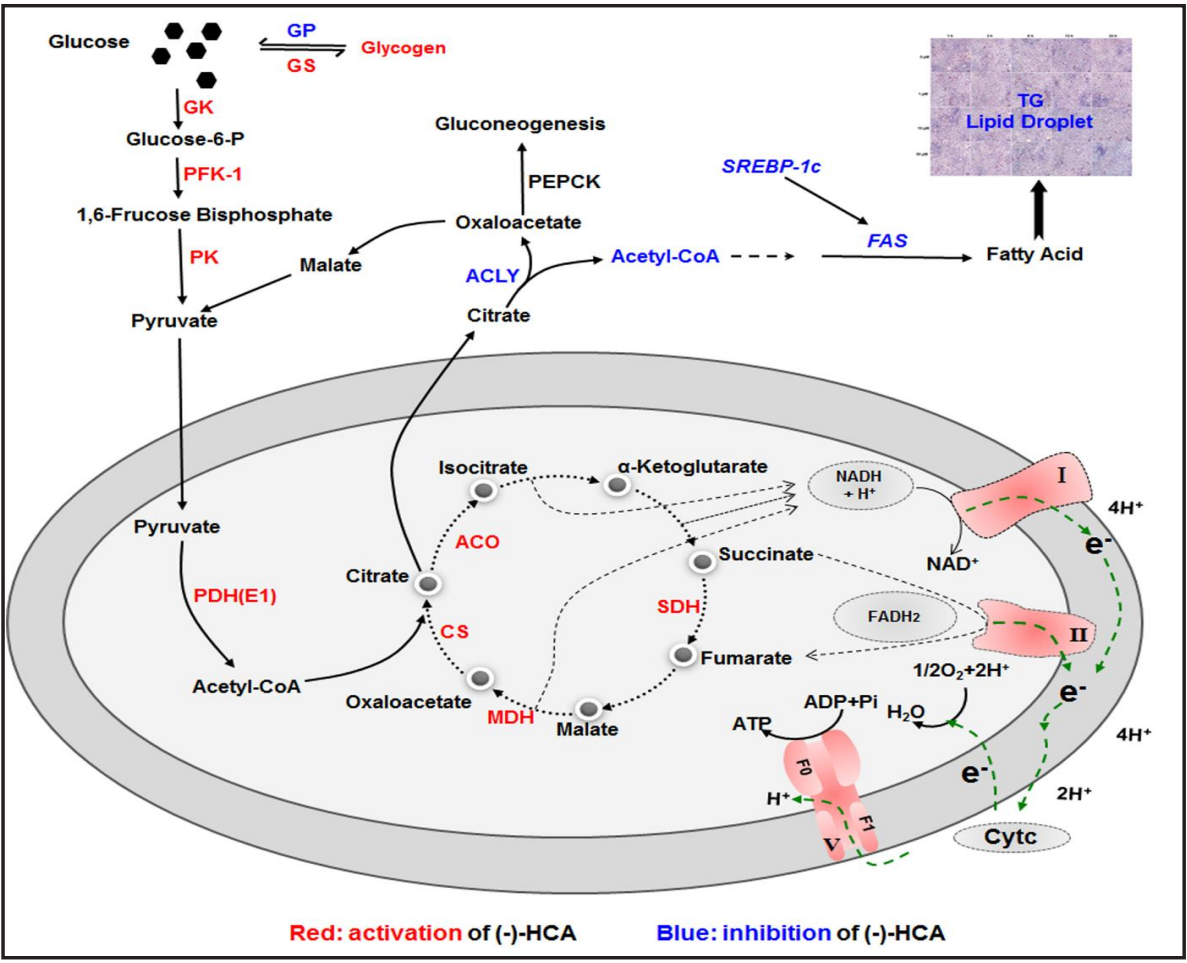
fat accumula-

tion in primary chicken hepatocytes, and this results provides a new biochemical mechanism from view energy metabolism perspective to explain the action of (-)-HCA reduced lipid deposition in broiler chickens. 


\section{Cellular Physiology Cell Physiol Biochem 2017;43:812-831 \begin{tabular}{l|l|l}
\hline and Biochemistry 10.1159/000481564 & $\begin{array}{l}\text { C } 2017 \text { The Author(s). Published by S. Karger AG, Basel } \\
\text { www.karger.com/cpb }\end{array}$ \\
\hline
\end{tabular} \\ Li et al.: Impact of (-)-HCA On Lipid Metabolism and Energy Metabolism}

metabolism in broiler chickens [29]. Taken the above data, we think that (-)-HCA treated decreased the triacylglycerol accumulation in primary chicken hepatocytes by a decreasing the supply of acetyl-CoA, which was mainly achieved by promotion of glucose catabolism and/or oxidative phosphorylation.

\section{Conclusion}

The present data demonstrated that (-)-HCA inhibited fatty acid synthesis by decreasing the supply of acetyl-CoA through the inhibition the ATP-citrate lyase activity; It also accelerated the glucose catabolism and energy metabolism, which eventually reduced fat accumulation in primary chicken hepatocytes (Fig. 12). In summary, our study provides a new biochemical mechanism relevant to (-)-HCA reduced lipid deposition in broiler chickens in term of energy metabolism.

\section{Acknowledgements}

This work was supported by the National Natural Science Foundation of China (NO. 31572483) and Priority Academic Program Development of Jiangsu Higher Education Institutions (PAPD).

\section{Competing interests}

The authors declare that they have no competing interests.

\section{References}

1 Li J, Wei X, Xie Q, Hoa Pham TT, Wei J, He P, Jiao Y, Xu X, Giang Nguyen TH, Wen Q Huang R: Protective Effects of 2-Dodecyl-6-Methoxycyclohexa-2, 5 -Diene-1, 4-Dione Isolated from Averrhoa Carambola L: (Oxalidaceae) Roots on High-Fat Diet-Induced Obesity and Insulin Resistance in Mice. Cell Physiol Biochem 2016;40:993-1004.

-2 Ahima RS: Digging deeper into obesity. J Clin Invest 2011;121:2076-2079.

- 3 Xi Y, Wu M, Li H, Dong S, Luo E, Gu M, Shen X, Jiang Y, Liu Y, Liu H: Baicalin Attenuates High Fat Diet-Induced Obesity and Liver Dysfunction: Dose-Response and Potential Role of CaMKK $\beta /$ AMPK/ACC Pathway. Cell Physiol Biochem 2015;35:2349-2359.

4 Wang L, Zhang N, Wang Z, Ai DM, Cao ZY, Pan HP: Decreased MiR-155 Level in the Peripheral Blood of Non-Alcoholic Fatty Liver Disease Patients may Serve as a Biomarker and may Influence LXR Activity. Cell Physiol Biochem 2016;39:2239-2248.

-5 Lou Y, Chen YD, Sun FR, Shi JP, Song Y, Yang J: Potential Regulators Driving the Transition in Nonalcoholic Fatty Liver Disease: a Stage-Based View. Cell Physiol Biochem 2017;41:239-251.

-6 Hagiwara H, Kaizu K, Uriu K, Noguchi T, Takagi I, Qie YL, Seki T, Ariga T: Expression of type-1 plasminogen activator inhibitor in the kidney of diabetic rat models. Thromb Res 2003;111:301-309.

-7 Huang MQ Zhou CJ, Zhang YP, Zhang XQ Xu W, Lin J, Wang PJ: Salvianolic Acid B Ameliorates Hyperglycemia and Dyslipidemia in $d b / d b$ Mice through the AMPK Pathway. Cell Physiol Biochem 2016;40:933-943.

8 Sartorius T, Drescher A, Panse M, Lastovicka P, Peter A, Weigert C, Kostenis E, Ullrich S, Häring HU: Mice Lacking Free Fatty Acid Receptor 1 (GPR40/FFAR1) are Protected Against Conjugated Linoleic AcidInduced Fatty Liver but Develop Inflammation and Insulin Resistance in the Brain. Cell Physiol Biochem 2015;35:2272-2284. 


\section{Cellular Physiology Cell Physiol Biochem 2017;43:812-831 and Biochemistry \begin{tabular}{l|l} 
DOI: 10.1159/000481564 & (c) 2017 The Author(s). Published by S. Karger AG, Basel \\
www.karger.com/cpb
\end{tabular}

9 Roy S, Rink C, Khanna S, Phillips C, Bagchi D, Bagchi M, Sen CK: Body weight and abdominal fat gene expression profile in response to a novel hydroxycitric acid-based dietary supplement. Gene Expr 2004;11:251-262.

10 Adeneye AA, Adeyemi 00, Agbaje EO: Anti-obesity and antihyperlipidaemic effect of Hunteria umbellata seed extract in experimental hyperlipidaemia. J Ethnopharmacol 2010;130:307-314.

11 Zeng L, Tang W, Yin J, Feng L, Li Y, Yao X, Zhou B: Alisol A 24-Acetate Prevents Hepatic Steatosis and Metabolic Disorders in HepG2 Cells. Cell Physiol Biochem 2016;40:453-464.

12 Raza H, John A, Howarth FC: Increased Oxidative Stress and Mitochondrial Dysfunction in Zucker Diabetic Rat Liver and Brain. Cell Physiol Biochem 2015;35:1241-1251.

-13 Kelly PJ, Clarke PM, Hayes AJ, Gerdtham UG, Cederholm J, Nilsson P, Eliasson B, Gudbjornsdottir S: Predicting mortality in people with type 2 diabetes mellitus after major complications: a study using Swedish National Diabetes Register data. Diabet Med 2014;31:954-962.

-14 Kang J, Ge C, Yu L, Li L, Ma H: Long-Term Administration of Dehydroepiandrosterone Accelerates Glucose Catabolism via Activation of PI3K/Akt-PFK-2 Signaling Pathway in Rats Fed a High-Fat Diet. PLoS ONE 2016;11:e0159077.

15 Harasiuk D, Baranowski M, Zabielski P, Chabowski A, Górski J: Liver X Receptor Agonist T0901317 Prevents Diacylglycerols Accumulation in the Heart of Streptozotocin-Diabetic Rats. Cell Physiol Biochem 2016;39:350-359.

16 Jena BS, Jayaprakasha GK, Singh RP, Sakariah KK: Chemistry and biochemistry of (-)-hydroxycitric acid from Garcinia. J Agric Food Chem 2002;50:10-22.

17 Tomita K, Okuhara Y, Shigematsu N, Suh H, Lim K: (-)-hydroxycitrate ingestion increases fat oxidation during moderate intensity exercise in untrained men. Biosci Biotechnol Biochem 2003;67:1999-2001.

18 Ohia SE, Opere CA, LeDay AM, Bagchi M, Bagchi D, Stohs SJ: Safety and mechanism of appetite suppression by a novel hydroxycitric acid extract (HCA-SX). Mol Cell Biochem 2002;238:89-103.

19 Kim JE, Jeon SM, Park KH, Lee WS, Jeong TS, Mcgregor RA, Choi MS: Does Glycine max leaves or Garcinia Cambogia promote weight-loss or lower plasma cholesterol in overweight individuals: a randomized control trial. Nutr J 2011;10:94.

-20 Fassina P, Scherer Adami F, Terezinha Zani V, Kasper Machado IC, Garavaglia J, Quevedo Grave MT, Ramos R, Morelo Dal Bosco S: The Effect of Garcinia Cambogia as Coadjuvant in the Weight Loss Process. Nutr Hosp 2015;32:2400-2408.

21 Ishihara K, Oyaizu S, Onuki K, Lim K, Fushiki T: Chronic (-)-hydroxycitrate administration spares carbohydrate utilization and promotes lipid oxidation during exercise in mice. J Nutr 2000;130:2990-2995.

22 Kim YJ, Kim K-Y, Kim MS, Lee JH, Lee KP, Park T: A mixture of the aqueous extract of Garcinia cambogia, soy peptide and l-carnitine reduces the accumulation of visceral fat mass in rats rendered obese by a high fat diet. Genes Nutr 2008;2:353-358.

23 Preuss HG, Bagchi D, Bagchi M, Rao CV, Dey DK, Satyanarayana S: Effects of a natural extract of (-)-hydroxycitric acid (HCA-SX) and a combination of HCA-SX plus niacin-bound chromium and Gymnema sylvestre extract on weight loss. Diabetes Obes Metab 2004;6:171-180.

-24 Cheng IS, Huang SW, Lu HC, Wu CL, Chu YC, Lee SD, Huang CY, Kuo CH: Oral hydroxycitrate supplementation enhances glycogen synthesis in exercised human skeletal muscle. Br J Nutr 2012;107:1048-1055.

-25 Sullivan AC, Hamilton JG, Miller ON, Wheatley VR: Inhibition of lipogenesis in rat liver by (-)-hydroxycitrate. Arch Biochem Biophys 1972;150:183-190.

26 Watson JA, Lowenstein JM: Citrate and the conversion of carbohydrate into fat. Fatty acid synthesis by a combination of cytoplasm and mitochondria. J Biol Chem 1970;245:5993-6002.

27 Chuah LO, Ho WY, Beh BK, Yeap SK: Updates on Antiobesity Effect of Garcinia Origin (-)-HCA. Evid Based Complement Alternat Med 2013;2013:751658.

28 Han N, Li L, Peng M, Ma H: (-)-Hydroxycitric Acid Nourishes Protein Synthesis via Altering Metabolic Directions of Amino Acids in Male Rats. Phytother Res 2016;30:1316-1329.

29 Peng M, Han J, Li L, Ma H: Suppression of fat deposition in broiler chickens by (-)-hydroxycitric acid supplementation: A proteomics perspective. Sci Rep 2016;6:32580.

30 Watson JA, Fang M, Lowenstein JM: Tricarballylate and hydroxycitrate: substrate and inhibitor of ATP: citrate oxaloacetate lyase. Arch Biochem Biophys 1969;135:209-217.

-31 Stallings WC, Blount JF, Srere PA, Glusker JP: Structural studies of hydroxycitrates and their relevance to certain enzymatic mechanisms. Arch Biochem Biophys 1979;193:431-448. 


\section{Cellular Physiology Cell Physiol Biochem 2017;43:812-831 and Biochemistry \begin{tabular}{l|l} 
DOI: 10.1159/000481564 & (c) 2017 The Author(s). Published by S. Karger AG, Basel \\
www.karger.com/cpb
\end{tabular}

-32 Sullivan AC, Triscari J, Hamilton JG, Miller ON: Effect of (-)-hydroxycitrate upon the accumulation of lipid in the rat. II. Appetite. Lipids 1974;9:129-134.

-33 Garland PB, Randle PJ, Newsholme EA: Citrate as an Intermediary in the Inhibition of Phosphofructokinase in Rat Heart Muscle by Fatty Acids, Ketone Bodies, Pyruvate, Diabetes, and Starvation. Nature 1963;200:169-170.

-34 Munday MR: Regulation of mammalian acetyl-CoA carboxylase. Biochem Soc Trans 2002;30:1059-1064.

-35 Leveille GA: In vitro hepatic lipogenesis in the hen and chick. Comp Biochem Physiol 1969;28:431-435.

-36 Astell KJ, Mathai ML, Su XQ: A review on botanical species and chemical compounds with appetite suppressing properties for body weight control. Plant Foods Hum Nutr 2013;68:213-221.

37 Vasques CA, Rossetto S, Halmenschlager G, Linden R, Heckler E, Fernandez MS, Alonso JL: Evaluation of the pharmacotherapeutic efficacy of Garcinia cambogia plus Amorphophallus konjac for the treatment of obesity. Phytother Res 2008;22:1135-1140.

-38 Hayamizu K, Hirakawa H, Oikawa D, Nakanishi T, Takagi T, Tachibana T, Furuse M: Effect of Garcinia cambogia extract on serum leptin and insulin in mice. Fitoterapia 2003;74:267-273.

-39 Wielinga PY, Wachters-Hagedoorn RE, Bouter B, van Dijk TH, Stellaard F, Nieuwenhuizen AG, Verkade HJ, Scheurink AJ: Hydroxycitric acid delays intestinal glucose absorption in rats. Am J Physiol Gastrointest Liver Physiol 2005;288:G1144-1149.

40 Griffin HD, Guo K, Windsor D, Butterwith SC: Adipose tissue lipogenesis and fat deposition in leaner broiler chickens. J Nutr 1992;122:363-368.

41 Zakrzewska B, Jezewska MM: Xanthine nad oxidoreductase from embryo liver of hen gallus gallus. Comp Biochem Physiol B 1990;97:141-144.

-42 Kennedy SW, Lorenzen A, James CA, Collins BT: Ethoxyresorufin-O-deethylase and porphyrin analysis in chicken embryo hepatocyte cultures with a fluorescence multiwell plate reader. Anal Biochem 1993;211:102-112.

43 Strober W: Trypan blue exclusion test of cell viability. Curr Protoc Immunol 2015;111:A3.B1-3.

-44 Howell G, 3rd, Mangum L: Exposure to bioaccumulative organochlorine compounds alters adipogenesis, fatty acid uptake, and adipokine production in NIH3T3-L1 cells. Toxicol In vitro 2011;25:394-402.

45 Lescuyer P, Strub JM, Luche S, Diemer H, Martinez P, Van Dorsselaer A, Lunardi J, Rabilloud T: Progress in the definition of a reference human mitochondrial proteome. Proteomics 2003;3:157-167.

46 Shen X, Liu L, Yin F, Ma H, Zou S: Effect of dehydroepiandrosterone on cell growth and mitochondrial function in TM-3 cells. Gen Comp Endocrinol 2012;177:177-186.

47 Vasques CA, Schneider R, Klein-Junior LC, Falavigna A, Piazza I, Rossetto S: Hypolipemic effect of Garcinia cambogia in obese women. Phytother Res 2014;28:887-891.

48 Hayamizu K, Ishii Y, Kaneko I, Shen M, Okuhara Y, Shigematsu N, Tomi H, Furuse M, Yoshino G, Shimasaki H: Effects of garcinia cambogia (Hydroxycitric Acid) on visceral fat accumulation: a double-blind, randomized, placebo-controlled trial. Curr Ther Res Clin Exp 2003;64:551-567.

-49 Loe YC, Bergeron N, Rodriguez N, Schwarz JM: Gas chromatography/mass spectrometry method to quantify blood hydroxycitrate concentration. Anal Biochem 2001;292:148-154.

50 Sullivan AC, Triscari J, Hamilton JG, Miller ON, Wheatley VR: Effect of (-)-hydroxycitrate upon the accumulation of lipid in the rat. I. Lipogenesis. Lipids 1974;9:121-128.

-51 Sullivan AC, Triscari J, Spiegel JE: Metabolic regulation as a control for lipid disorders. II. Influence of (--)-hydroxycitrate on genetically and experimentally induced hypertriglyceridemia in the rat. Am J Clin Nutr 1977;30:777-784.

-52 Saito M, Ueno M, Ogino S, Kubo K, Nagata J, Takeuchi M: High dose of Garcinia cambogia is effective in suppressing fat accumulation in developing male Zucker obese rats, but highly toxic to the testis. Food Chem Toxicol 2005;43:411-419.

53 Deshmukh NS, Bagchi M, Yasmin T, Bagchi D: Safety of a Novel Calcium/Potassium Saltof (-)-Hydroxycitric Acid (HCA-SX): II.Developmental Toxicity Study in Rats. Toxicol Mech Methods 2008;18:443-451.

54 Deshmukh NS, Bagchi M, Yasmin T, Bagchi D: Safety of a Novel Calcium/Potassium Salt of Hydroxycitric Acid (HCA-SX): I. Two-Generation Reproduction Toxicity Study. Toxicol Mech Methods 2008;18:433-442.

55 Lopez AM, Kornegay J, Hendrickson RG: Serotonin toxicity associated with Garcinia cambogia over-thecounter supplement. J Med Toxicol 2014;10:399-401.

-56 Preuss HG, Rao CV, Garis R, Bramble JD, Ohia SE, Bagchi M, Bagchi D: An overview of the safety and efficacy of a novel, natural(-)-hydroxycitric acid extract (HCA-SX) for weight management. J Med 2004;35:33-48. 


\section{Cellular Physiology Cell Physiol Biochem 2017;43:812-831

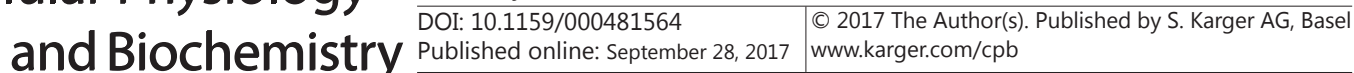

57 Hayamizu K, Tomi H, Kaneko I, Shen M, Soni MG, Yoshino G: Effects of Garcinia cambogia extract on serum sex hormones in overweight subjects. Fitoterapia 2008;79:255-261.

58 Nisha VM, Priyanka A, Anusree SS, Raghu KG: (-)-Hydroxycitric acid attenuates endoplasmic reticulum stress-mediated alterations in 3T3-L1 adipocytes by protecting mitochondria and downregulating inflammatory markers. Free Radic Res 2014;48:1386-1396.

59 Han J, Li L, Wang D, Ma H: (-)-Hydroxycitric acid reduced fat deposition via regulating lipid metabolismrelated gene expression in broiler chickens. Lipids Health Dis 2016;15:37.

60 Mohlapo TD, Ng'ambi JW, Norris D, Malatje MM: Effect of Hoodia gordonii meal supplementation at finisher stage on productivity and carcass characteristics of Ross 308 broiler chickens. Trop Anim Health Prod 2009;41:1591-1596.

-61 Gursel FE, Ates A, Bilal T, Altiner A: Effect of dietary Garcinia cambogia extract on serum essential minerals (calcium, phosphorus, magnesium) and trace elements (iron, copper, zinc) in rats fed with high-lipid diet. Biol Trace Elem Res 2012;148:378-382.

62 Liu G, Han N, Han J, Chen D, Kang J, Ma H: Garcinia Cambogia Extracts Prevented Fat Accumulation via Adiponectin-AMPK Signaling Pathway in Developing Obesity Rats. Food Sci and Technol Res 2015;21:835845 .

63 Marquez F, Babio N, Bullo M, Salas-Salvado J: Evaluation of the safety and efficacy of hydroxycitric acid or Garcinia cambogia extracts in humans. Crit Rev Food Sci Nutr 2012;52:585-594.

-64 Al FF, Fayyaz S, Japtok L, Kleuser B: Involvement of Sphingosine 1-Phosphate in Palmitate-Induced NonAlcoholic Fatty Liver Disease. Cell Physiol Biochem 2016;40:1637-1645.

65 Mehlem A, Hagberg CE, Muhl L, Eriksson U, Falkevall A: Imaging of neutral lipids by oil red 0 for analyzing the metabolic status in health and disease. Nat Protoc 2013;8:1149-1154.

66 Kang ES, Ham SA, Hwang JS, Lee CK, Seo HG: Effects of Garcinia cambogia Extract on the Adipogenic Differentiation and Lipotoxicity. Korean J Food Sci An 2013;33:411-416.

-67 Hasegawa N: Garcinia extract inhibits lipid droplet accumulation without affecting adipose conversion in 3T3-L1 cells. Phytother Res 2001;15:172-173.

68 Kim MS, Kim JK, Kwon DY, Park R: Anti-adipogenic effects of Garcinia extract on the lipid droplet accumulation and the expression of transcription factor. Biofactors 2004;22:193-196.

-69 Brown MS, Goldstein JL: The SREBP pathway: regulation of cholesterol metabolism by proteolysis of a membrane-bound transcription factor. Cell 1997;89:331-340.

70 Bitter A, Nüssler AK, Thasler WE, Klein K, Zanger UM, Schwab M, Burk O: Human sterol regulatory elementbinding protein 1a contributes significantly to hepatic lipogenic gene expression. Cell Physiol Biochem 2015;35:803-815.

71 Knight BL, Hebbachi A, Hauton D, Brown AM, Wiggins D, Patel DD, Gibbons GF: A role for PPARalpha in the control of SREBP activity and lipid synthesis in the liver. Biochem J 2005;389:413-421.

72 Zhang Y, Yin L, Hillgartner FB: SREBP-1 integrates the actions of thyroid hormone, insulin, cAMP, and medium-chain fatty acids on ACCalpha transcription in hepatocytes. J Lipid Res 2003;44:356-368.

73 Rocchi S, Auwerx J: Peroxisome proliferator-activated receptor gamma, the ultimate liaison between fat and transcription. Br J Nutr 2000;84:S223-227.

74 Agius L: Role of glycogen phosphorylase in liver glycogen metabolism. Mol Aspects Med 2015;46:34-45.

75 Okamoto Y, Ogawa W, Nishizawa A, Inoue H, Teshigawara K, Kinoshita S, Matsuki Y, Watanabe E, Hiramatsu R, Sakaue H, Noda T, Kasuga M: Restoration of glucokinase expression in the liver normalizes postprandial glucose disposal in mice with hepatic deficiency of PDK1. Diabetes 2007;56:1000-1009.

76 Usenik A, Legisa M: Evolution of allosteric citrate binding sites on 6-phosphofructo-1-kinase. PLoS ONE 2010;5:e15447.

-77 Ciszak EM, Korotchkina LG, Dominiak PM, Sidhu S, Patel MS: Structural basis for flip-flop action of thiamin pyrophosphate-dependent enzymes revealed by human pyruvate dehydrogenase. J Biol Chem 2003;278:21240-21246.

78 Jaimes R, 3rd., Kuzmiak-Glancy S, Brooks DM, Swift LM, Posnack NG, Kay MW: Functional response of the isolated, perfused normoxic heart to pyruvate dehydrogenase activation by dichloroacetate and pyruvate. Pflugers Arch 2016;468:131-142.

-79 Weinman EO, Strisower EH, Chaikoff IL: Conversion of fatty acids to carbohydrate; application of isotopes to this problem and role of the Krebs cycle as a synthetic pathway. Physiol Rev 1957;37:252-272. 


\section{Cellular Physiology Cell Physiol Biochem 2017;43:812-831 \begin{tabular}{ll|l} 
and Biochemistry 10.1159/000481564 & $\begin{array}{l}\text { O 2017 The Author(s). Published by S. Karger AG, Basel } \\
\text { www.karger.com/cpb }\end{array}$ \\
\cline { 2 - 3 }
\end{tabular} \\ Li et al.: Impact of (-)-HCA On Lipid Metabolism and Energy Metabolism}

80 Jones JG: Hepatic glucose and lipid metabolism. Diabetologia 2016;59:1098-1103.

81 Hausladen A, Fridovich I: Measuring nitric oxide and superoxide: rate constants for aconitase reactivity. Methods Enzymol 1996;269:37-41.

82 Minarik P, Tomaskova N, Kollarova M, Antalik M: Malate dehydrogenases--structure and function. Gen Physiol Biophys 2002;21:257-265.

-83 Rutter J, Winge DR, Schiffman JD: Succinate dehydrogenase - Assembly, regulation and role in human disease. Mitochondrion 2010;10:393-401.

84 Hochstein LI, Dalton BP: Studies of a halophilic NADH dehydrogenase. I. Purification and properties of the enzyme. Biochim Biophys Acta 1973;302:216-228.

-85 Suhane S, Berel D, Ramanujan VK: Biomarker signatures of mitochondrial NDUFS3 in invasive breast carcinoma. Biochem Biophys Res Commun 2011;412:590-595.

86 Emahazion T, Beskow A, Gyllensten U, Brookes AJ: Intron based radiation hybrid mapping of 15 complex I genes of the human electron transport chain. Cytogenet Cell Genet 1998;82:115-119.

87 Fillingame RH: The proton-translocating pumps of oxidative phosphorylation. Annu Rev Biochem 1980;49:1079-1113. 